\title{
The accumulation model of organic matters for the Niutitang Formation shale and its control on the pore structure: a case study from Northern Guizhou
}

\author{
Teng $\mathrm{Li}^{1,2} \cdot$ Hui Gao ${ }^{1}$ Chen Wang ${ }^{1} \cdot$ Zhilin Cheng $^{1} \cdot$ Yanning Yang ${ }^{3} \cdot$ Jie Zhan ${ }^{4,5}$
}

Received: 28 September 2021 / Accepted: 29 December 2021 / Published online: 7 January 2022

(c) The Author(s) 2022

\begin{abstract}
Shale gas reservoir is a fine-grained sedimentary rock with component of clastic particles and organic matters, and the accumulation of the organic matters would determine the effective development of shale gas. The paleoclimate, detrital influx, redox of the water and paleoproductivity are effective geochemical indicators that could help to find the favorable shale gas reservoir stratum. In this study, the shale samples collected from Niutitang Formation (Northern Guizhou, China) were launched the measurements of the content of major elements and trace elements, and the characteristics of geochemical indicators were analyzed, which can be used to discuss the accumulation model of organic matters. Besides, the pore structure of shale sample controlled by the enrichment of organic matters is also discussed. The paleoclimate is dominant cold and dry, and it changes to warm and humid at the later Niutitang period, and the detrital influx also increased at the later Niutitang period; the water environment of Niutitang Formation shale presents as reductive, and the paleoproductivity of the Niutitang Formation shale is commonly high. The enrichment of organic matters in the Niutitang Formation is dominantly controlled by the redox of the water, while the hydrothermal activity and the paleoproductivity lead to the difference enrichment of organic matters in the Niutitang Formation shale. The accumulation model of organic matters also influences the characteristics of pore structure from the Niutitang Formation shale, and the pore structure could be divided into two types. The shale with high content of organic matters also features high content of quartz and pyrite, and these minerals contribute to the preservation of pore space in the shale, while that of the clay minerals is contrary. The high content of organic matters and preferable pore characteristics indicate the Niutitang Formation favors the development of shale gas, especially that for the lower Niutitang Formation.
\end{abstract}

Keywords Niutitang Formation shale - Geochemical indicators · Accumulation of organic matter · Pore structure · Northern Guizhou

Teng Li

liteng2052@163.com

1 College of Petroleum Engineering, Xi' an Shiyou University, Xi' an 710065, China

2 Xi'an Key Laboratory of Tight Oil (Shale Oil), Xi'an Shiyou University, Xi' an 710065, China

3 No. 6 Oil Production Plant, Changqing Oilfield Company, PetroChina, Dingbian 718600, China

4 State Key Laboratory of Shale Oil and Gas Enrichment Mechanisms and Effective Development, Beijing 100871, China

5 Development and Management for Low To Ultra-Low Permeability Oil \& Gas Reservoirs in West China, Ministry of Education, Xi' an Shiyou University, Xi' an 710065, China

\section{Introduction}

Shale gas has attracted the attention of researchers in the unconventional oil and gas field recent years. The exploration and development of shale gas dominantly focus on the Middle Triassic Yanchang Formation, Lower Silurian Longmaxi Formation and Lower Cambrian Niutitang Formation in China (Wang et al. 2020a, b). The Longmaxi Formation shale gas has successfully conducted commercial development, while that for the Yanchang Formation shale gas just is still in the primary exploration stage. As the key development stratum of shale gas in South China, the Niutitang Formation shale gas in Hubei Province has acquired major breakthrough (Wang et al. 2020a, b). 
The accumulation of organic matter is the result of multifactors, including sedimentary environment, tectonic movement, the preservation of organic matter and so on. The difference accumulation of organic matters could be investigated with the geochemical method with various geochemical indicators (Ross and Bustin 2009a, b). The organic matter accumulation models could be summarized with two types, preservation model and productivity model, respectively (Talbot 1988; Carroll and Bohacs 1999). The preservation model concentrates on the water environment that controls the preservation of the organic matters (Demaison and Moore 1980; Arthur and Sageman 1994; Arthur et al. 1998), while the productivity model persists the organisms contribute to the preservation of organic matter (Wignall and Newton 2001). In fact, the accumulation of organic matters commonly shows the comprehensive effect of preservation model and productivity model, especially that for the marine-continental transitional shale (Liu et al. 2018). Geochemistry characteristics are effective method to recover the paleogeographical and paleoclimate, which would finally summarize the difference accumulation of the organic matter. There are several geochemical indicators that could be used. Chemical index of alteration (CIA) is commonly utilized to analyze the paleoclimate (Wedepohl 1971; Nesbitt and Young 1982; McLennan 1993; Ross and Bustin 2009a, b); the ratio of content of $\mathrm{SiO}_{2}$ and $\mathrm{Al}_{2} \mathrm{O}_{3}\left(\mathrm{SiO}_{2} / \mathrm{Al}_{2} \mathrm{O}_{3}\right)$, the ratio of content of $\mathrm{MnO}$ and $\mathrm{TiO}_{2}\left(\mathrm{MnO} / \mathrm{TiO}_{2}\right)$ and the ratio of content of yttrium and holmium (Y/Ho) are used to indicate the amount of the detrital influx (Ryuichi et al. 1982; Webb and Kamber 2000); the ratio of content of vanadium and (vanadium plus nickel) $(\mathrm{V} /(\mathrm{V}+\mathrm{Ni}))$, the ratio of content of vanadium and chromium ( $\mathrm{V} / \mathrm{Cr}$ ), the ratio of content of nickel and cobalt $(\mathrm{Ni} / \mathrm{Co}), \mathrm{EF}_{\mathrm{Mo}}, \mathrm{EF}_{\mathrm{U}}, \mathrm{EF}_{\mathrm{V}}, \mathrm{EF}_{\mathrm{Ni}}$, the ratio of content of uranium and thorium (U/Th) and the ratio of content of cuprum and zincum $(\mathrm{Cu} / \mathrm{Zn})$ could indicate the redox environment of water (Algeo and Maynard 2004; Ross and Bustin 2009b; Pi et al. 2014; Zhu et al. 2018), and the ratio of content of phosphorus and titanium $(\mathrm{P} / \mathrm{Ti})$ and ratio of content of barium and aluminum $(\mathrm{Ba} / \mathrm{Al})$ could present the paleoproductivity (Dean et al. 1997; Algeo et al. 2011; Liu et al. 2018). Currently, the accumulation characteristics of organic matter with the geochemical method for Niutitang Formation shale in China mainly focus in south of Yangtze platform (Liu et al. 2015, 2016; Xia et al. 2015; Wu et al. 2017; Zhou et al. 2017, 2019; Li et al. 2018, 2019; Zhang et al. 2018; Ma et al. 2019; Awan et al. 2020). The lithofacies of Niutitang Formation shale in South China could be divided into five types, including organic matter-rich siliceous shale, silty-siliceous shale, argillaceous shale, calcareous shale and silty-siliceous mixed shale (Yang et al. 2016; Wu et al. 2017).

The pores in the Niutitang Formation shale are dominantly mineral matrix pore with poor connectivity, and the organic pores are rare (Wang et al. 2016a). The shape of the Niutitang Formation pores is various, including conical, ink bottle, spherical, elliptical, beaded, irregular, plate-like intersecting micro-fractures and so on (Sun et al. 2020). The micropores in the Niutitang Formation shale mainly occur in the organic matter (Sun et al. 2016), while large amount of these pores are closed pore (Sun et al. 2018). The mesopores and macro-pores are dominantly contributed by the minerals (Sun et al. 2016). The content of TOC, quartz and clay minerals and the thermal evolution degree are the key factors that determine the characteristics of pore structure in the Niutitang Formation shale (Shang et al. 2021; Wang et al. 2021). The thermal evolution degree determines the development of the organic matter. When $R_{\mathrm{o}}$ of shale is less than $1.5 \%$, the amounts of the organic pores are less, and the pore aperture is also small. Once the $R_{\mathrm{o}}$ exceeds $3 \%$, the organic pores in the shale nearly disappear (Wang et al. 2016a, b, c; Gu et al. 2018; Wang et al. 2020a, b). The content of quartz is high in the Niutitang Formation shale (Qin et al. 2019), and the quartz presents with five different types, silt-size/sand-size detrital quartz, siliceous skeletons, overgrowth nucleated around detrital quartz, matrix-dispersed microcrystalline quartz and aggregates of euhedral quartz, respectively, and the authigenic quartz is the dominant type (Dong et al. 2021). However, Liu et al. (2018) reported that the high content of quartz in the Niutitang Formation shale profits from the biogenetic quartz (Dong et al. 2021). For the Niutitang Formation shale in Guizhou, the content of quartz is also high, and the quartz comes from both continental detrital quartz and biogenetic quartz (Sun et al. 2021). The intergranular pores and organic pores are developed in Niutitang Formation siliceous shale (Niu et al. 2021), while Wang et al. $(2020 \mathrm{a}, \mathrm{b})$ found that the organic pores are rarely developed in the Niutitang Formation shale. For the argillaceous shale in the Niutitang Formation, the intergranular pores are less developed, and the cleavage-sheet intraparticle pores are developed in the clay minerals (Niu et al. 2021). The content of TOC $(<6.5 \%)$ and quartz favor the development of pores for the siliceous shale, especially that for the micropores (Wang et al. 2016b, c; Niu et al. 2021). The quartz features as rigid mineral, it can resist a certain compaction, which will finally preserve the pore space (Xi et al. 2019). Besides, the dissolution of feldspar could also promote the development of pores (Guo et al. 2021). When it comes to the argillaceous shale, the pore structure characteristics are mainly influenced by the content of illite (Niu et al. 2021).

There have been a detailed study on the accumulation of organic matters and the characteristics of pore structure for the Niutitang Formation shale in South China, while the accumulation characteristics of organic matter for Niutitang Formation shale in North Guizhou is rare. The accumulation of organic matter is influenced by the sedimentary environment, and it will lead to various lithology characteristics, 
which will finally determine the different pore structure of shale. In this study, the Niutitang Formation shale samples were collected from a shale gas well in Northern Guizhou, with the detailed analysis of the characteristics of major and trace elements, the accumulation characteristics of organic matters is discussed with multi-geochemical indicators; combined with the lithology characteristics of the Niutitang Formation, the pore structure characteristics influenced by the organic matter accumulation model is studied.

\section{Samples and method}

\section{The geological setting and samples}

The study area locates in the northern Guizhou Province, China. Guizhou has experienced the Xuefeng movement, Caledonian movement, Hercynian movement, Indo-China movement, Yanshan movement and Himalayan movement during the geologic history, the complicated tectonic movements lead to the seven secondary structure units in Guizhou currently (Fig. 1). At the later period of Mesoproterozoic
Era, the sedimentary environment of the study area is marine, and it continuously expands to the north. At Silurian, the continental crust transforms from active continental margin to stable platform and finally turns into stable continental crust at the late Silurian. The shale samples used in this study collected from a shale gas well in Guizhou Province, and the nine shale samples were collected with interval method (Fig. 2). To avoid the probable sample pollution, the collected shale samples were packaged with independent plastic bag.

\section{Measurements}

The content of TOC is measured with the TOC-Control $\mathrm{L} / \mathrm{V}$ organic carbon analyzer produced by Shimadzu, and the determination of total organic carbon in sedimentary rock (GB/T 19,145-2003, Chinese Standard) is consulted. Firstly, the shale samples were crushed with a size less than 80 mesh; following that, excess dilute hydrochloric acid was added to get rid of the inorganic carbon in the samples; after that, the shale samples would be burned with oxygen under high temperature, which would change the TOC to carbon
Fig. 1 The location of the research area ( modified from Liu et al. 2018)

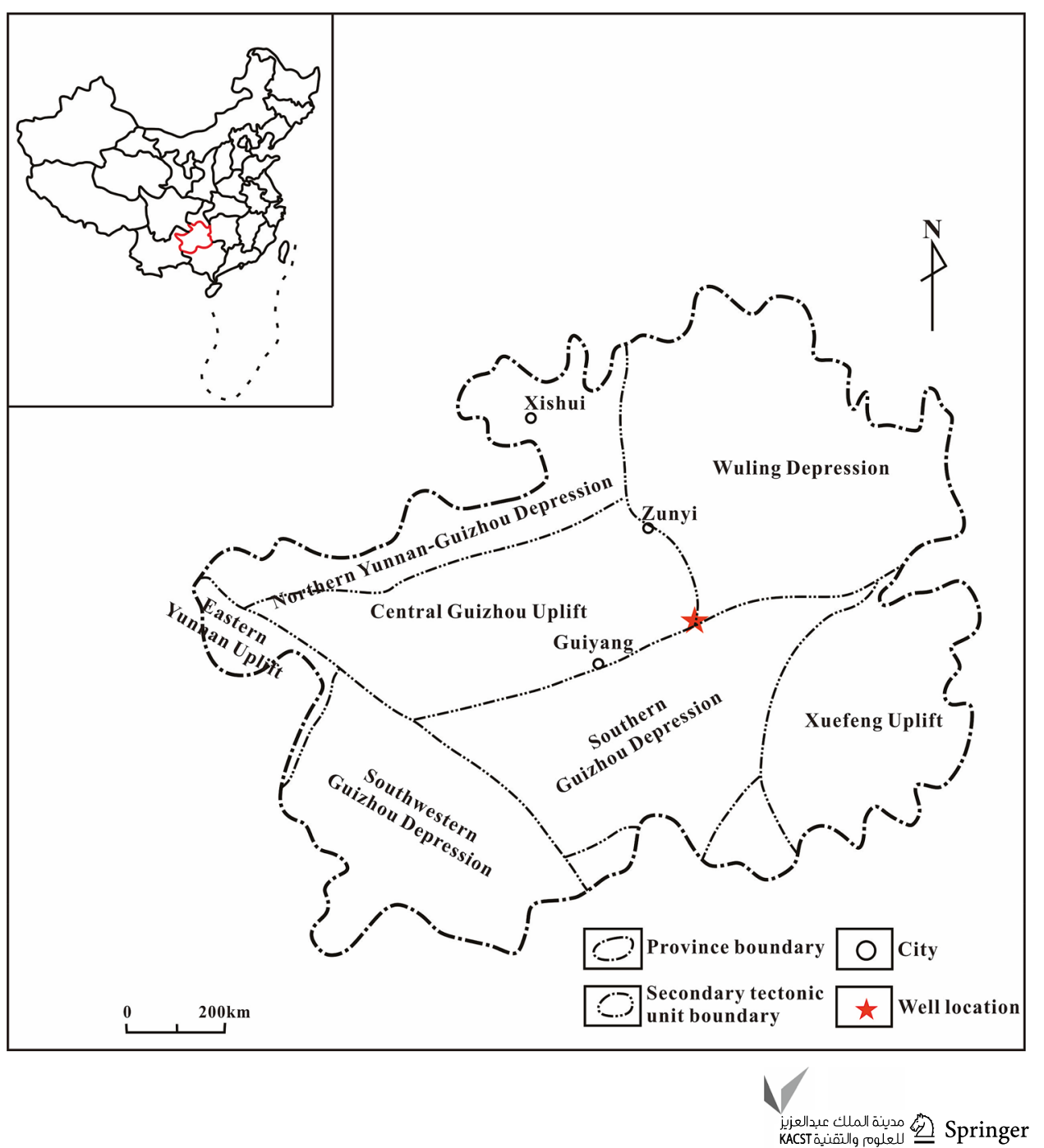




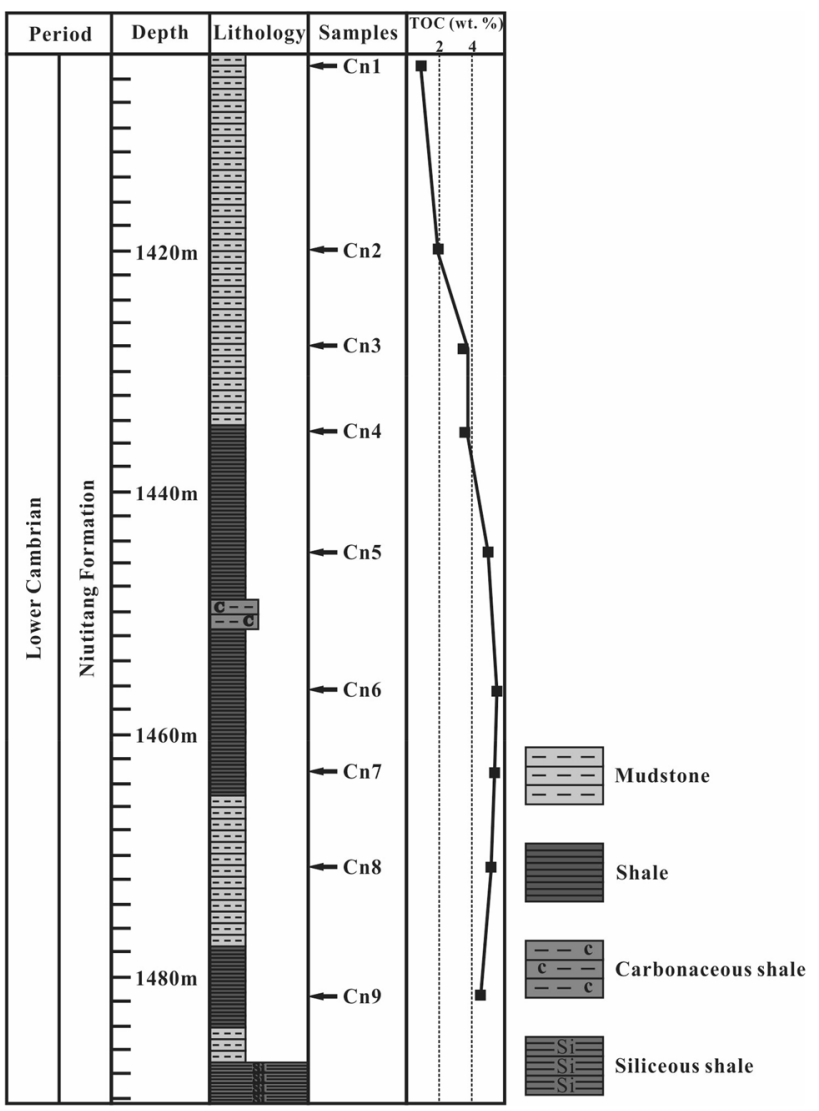

Fig. 2 The stratigraphic column and vertical distribution of TOC content of the Niutitang Formation

dioxide; finally, the content of TOC was measured with the infrared detector. The parallel samples were set, the deviation of the measurement result less than $0.1 \%$ is thought to be reliable.

The shale samples were crushed to 200 mesh before the geochemical characteristics are analyzed. The content of the major elements were measured with the X-ray fluorescence spectrometry method according to the methods for chemical analysis of silicate rocks (GB/T 14,506.28-2010, Chinese Standard). The shale samples would be prepared with the glass melting method and then be analyzed with the Axios Max X-ray fluorescence spectrometry analyzer. With the chemical reagent-general rules for inductively coupled plasma mass spectrometry (GB/T 39,486-2020, Chinese Standard), the content of the trace elements was measured with the inductively coupled plasma mass spectrometer. Firstly, the crushed shale samples (approximately $25 \mathrm{mg}$ ) would be dried under $105{ }^{\circ} \mathrm{C}$; secondly, the dried samples would be placed in the seal gland, with $0.5 \mathrm{ml} \mathrm{HF}$ solution, the samples would be dried again at $120{ }^{\circ} \mathrm{C}$ to dissolve the $\mathrm{SiO}_{2}$ in the samples; thirdly, the samples would be handled with the mixture of $\mathrm{HF}$ solution $(1 \mathrm{ml})$ and $\mathrm{HNO}_{3}(0.5 \mathrm{ml})$ under $190{ }^{\circ} \mathrm{C}$ for $24 \mathrm{~h}$; after that, the samples would be soaked with the $30 \%(\mathrm{v} / \mathrm{v}) \mathrm{HNO}_{3}$ under $130{ }^{\circ} \mathrm{C}$ for another $3 \mathrm{~h}$; finally, the samples would be cooled and analyzed. The accuracy is controlled below $5 \%$.

The view of scanning electron microscope (SEM) was launched with the MAIA3 model 2016 (LM) ultra-highresolution field emission scanning electron microscope. The shale samples would be polished with the Fischione argon ion polishing instrument, then the surface of the samples would be sprayed with gold. With a size of $10 \mathrm{~mm} \times 10 \mathrm{~mm} \times 1 \mathrm{~mm}$, the D8 ADVANCE X-ray diffraction analyzer was used to view the pore structure characteristics.

With the determination of the specific surface area of solids by gas adsorption using the BET method (GB/T 19,587-2017, Chinese Standard), the pore structure of the shale samples was measured with the TriStar II specific surface area analyzer.

The enrichment factor (EF) of various elements is commonly used to describe the enrichment degree, which can reflect the deviation degree of the element in the shale samples when it compares with the average marine shale (Wedepohl 1971), and it can be calculated with Eq. (1) (Ross and Bustin 2009b).

$\mathrm{EF}=(\text { element } / \mathrm{Al})_{\text {sample }} /(\text { element } / \mathrm{Al})_{\text {averageshale }}$

CIA could be acquire as follow,

$$
\mathrm{CIA}=100 \times\left[\mathrm{Al}_{2} \mathrm{O}_{3} /\left(\mathrm{Al}_{2} \mathrm{O}_{3}+\mathrm{CaO} *+\mathrm{Na}_{2} \mathrm{O}+\mathrm{K}_{2} \mathrm{O}\right)\right]
$$

where $\mathrm{CaO}^{*}$ is the content of $\mathrm{CaO}$, it should be adjusted with the content of $\mathrm{P}_{2} \mathrm{O}_{5}, \mathrm{CaO}_{\text {adjust }}=\mathrm{CaO}-\mathrm{P}_{2} \mathrm{O}_{5} \times 10 / 3$, when $\mathrm{CaO}_{\text {adjust }}>\mathrm{Na}_{2} \mathrm{O}, \mathrm{CaO}^{*}=\mathrm{Na}_{2} \mathrm{O}$; if not, $\mathrm{CaO} *=\mathrm{CaO}_{\text {adjust }}$. The contents of the elements used in Eq. (2) should be molar percent form (McLennan 1993).

\section{Results}

\section{TOC characteristics}

The content of TOC ranges from 0.90 to $5.54 \%$ for the Niutitang Formation shale. Except for $\mathrm{Cn} 1$ and $\mathrm{Cn} 2$ samples, the content of TOC for the shale samples exceeds $2 \%$. It can be found that the content of TOC is higher for the lower Niutitang Formation shale, and it tends to be decrease for the upper Niutitang Formation shale (Fig. 2).

\section{Major elements geochemistry characteristics}

The three end-member figure is used to present the content of the dominant inorganic minerals, including $\mathrm{SiO}_{2}, \mathrm{Al}_{2} \mathrm{O}_{3}$ and $\mathrm{CaO}$. Figure 3 shows the Niutitang Formation shale 


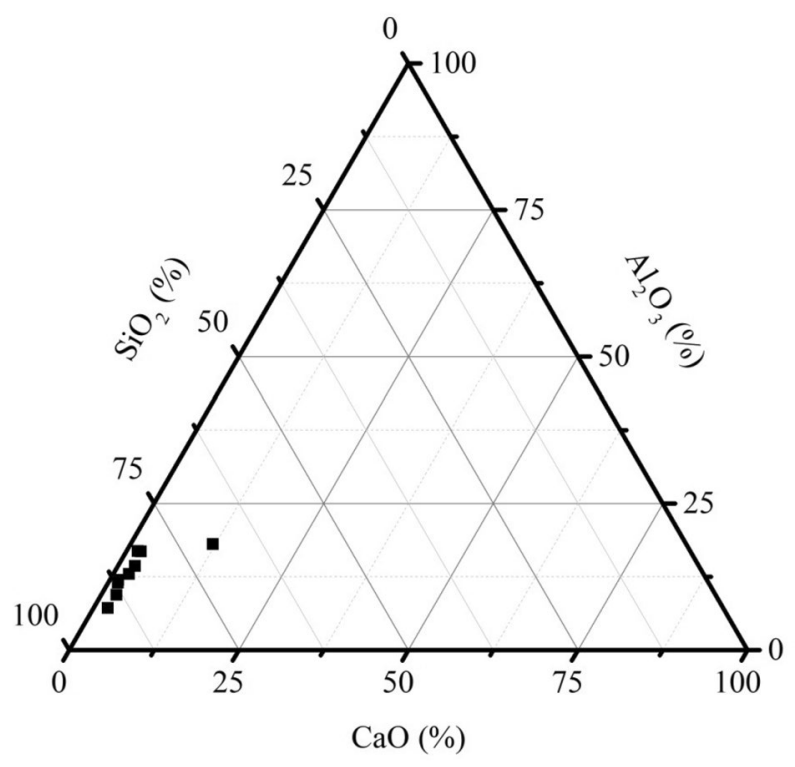

Fig. 3 Ternary diagram of quartz, clays and carbonates in Niutitang Formation shale samples

feature as $\mathrm{SiO}_{2}$ enrichment. The content of $\mathrm{SiO}_{2}$ ranges from 50.12 to $71.38 \%$, the content of $\mathrm{Al}_{2} \mathrm{O}_{3}$ varies from 5.64 to $13.23 \%$, and that for $\mathrm{CaO}$ ranges from 0.97 to $8.69 \%$. The lower Niutitang Formation shale features higher content of $\mathrm{SiO}_{2}$ than that of upper Niutitang Formation shale, while that for the $\mathrm{Al}_{2} \mathrm{O}_{3}$ and $\mathrm{CaO}$ is contrary (Table 1).

Ferrum $(\mathrm{Fe})$, calcium $(\mathrm{Ca})$, sodium $(\mathrm{Na})$ and phosphorus $(\mathrm{P})$ present enrichment for the Niutitang Formation shale, potassium $(\mathrm{K})$ and titanium $(\mathrm{Ti})$ feature as relative enrichment, while magnesium $(\mathrm{Mg})$ and manganese $(\mathrm{Mn})$ show a certain deficit (Fig. 4). The higher $\mathrm{EF}_{\mathrm{K}}$ is commonly related to the illite and talc in the shale (Yarincik et al. 2000; Ross and Bustin 2008; Chen et al. 2016). The lower $\mathrm{EF}_{\mathrm{Mg}}$ indicates the lower concentration of $\mathrm{Mg}$ and $\mathrm{K}$ in the clay minerals, which is related to the lack of

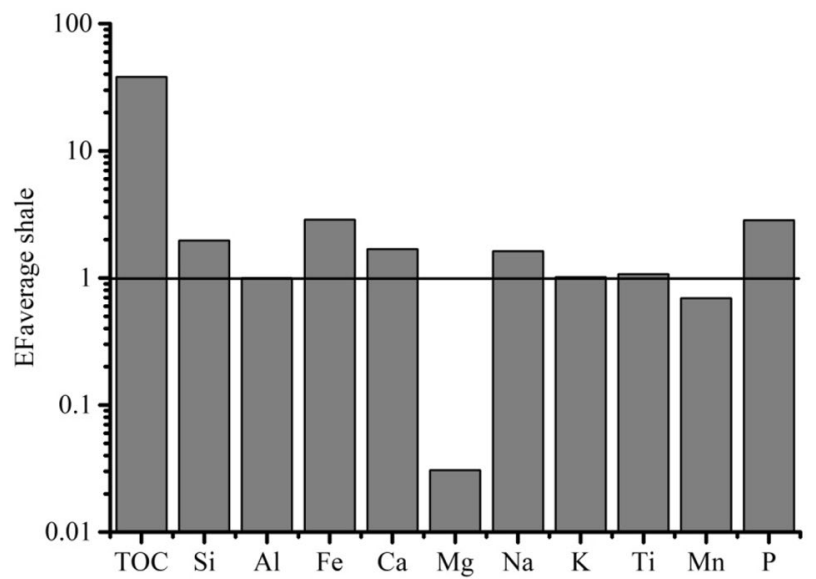

Fig. 4 Enrichment factors of TOC and major elements in Niutitang Formation shale samples

the kaolinite (Ross and Bustin 2008). The enrichment of $\mathrm{Mg}$ may also have a relationship with dolomite (Ross and Bustin 2008), and the lower $\mathrm{EF}_{\mathrm{Mg}}$ also means the lower content of dolomite in the Niutitang Formation shale. $\mathrm{Na}$ features enrichment, and this is mainly due to the high content of feldspar, especially the anorthose (Wedepohl 1971; Ross and Bustin 2008; Liu et al. 2018). The enrichment of $\mathrm{Fe}$ and $\mathrm{Ca}$ indicates the possible high content of pyrite, siderite and carbonate minerals in the Niutitang Formation shale (Zeng et al. 2015; Liu et al. 2018). Ti is stable element in the sediments, the good relationship between $\mathrm{Al}_{2} \mathrm{O}_{3}$ and $\mathrm{TiO}_{2}$ indicates that the Ti could both exist in the clay mineral crystal and the detrital influx (Ross and Bustin 2009a; Liu et al. 2018) (Fig. 5). The higher Mn concentration commonly accompanies with higher concentration of $\mathrm{Al}$ and $\mathrm{Ca}$ and lower concentration of silicon $(\mathrm{Si})$, the $\mathrm{EF}_{\mathrm{Mn}}$ of Niutitang Formation shale indicates that $\mathrm{Mn}$ may not come from the self-manganese carbonate (Ross and Bustin 2008) (Fig. 6).

Table 1 Major oxides, TOC and CIA of the Niutitang Formation shales

\begin{tabular}{|c|c|c|c|c|c|c|c|c|c|c|c|c|}
\hline \multirow[t]{2}{*}{ Sample } & \multirow[t]{2}{*}{ TOC /wt. \% } & \multicolumn{10}{|c|}{ Major oxides $1 \%$} & \multirow[t]{2}{*}{ CIA } \\
\hline & & $\mathrm{SiO}_{2}$ & $\mathrm{Al}_{2} \mathrm{O}_{3}$ & $\mathrm{Fe}_{2} \mathrm{O}_{3}+\mathrm{FeO}$ & $\mathrm{CaO}$ & $\mathrm{MgO}$ & $\mathrm{Na}_{2} \mathrm{O}$ & $\mathrm{K}_{2} \mathrm{O}$ & $\mathrm{TiO}_{2}$ & $\mathrm{MnO}$ & $\mathrm{P}_{2} \mathrm{O}_{5}$ & \\
\hline Cn1 & 0.90 & 50.12 & 13.00 & 5.45 & 8.69 & 0.08 & 1.04 & 2.81 & 0.60 & 0.06 & 0.16 & 72.70 \\
\hline $\mathrm{Cn} 2$ & 1.95 & 63.68 & 13.23 & 4.58 & 1.68 & 0.07 & 2.29 & 2.66 & 0.58 & 0.05 & 0.14 & 72.76 \\
\hline $\mathrm{Cn} 3$ & 3.47 & 61.69 & 12.77 & 5.98 & 1.23 & 0.05 & 2.22 & 2.65 & 0.53 & 0.04 & 0.16 & 72.38 \\
\hline $\mathrm{Cn} 4$ & 3.58 & 62.34 & 10.77 & 6.00 & 1.86 & 0.05 & 1.46 & 2.37 & 0.45 & 0.04 & 0.60 & 73.77 \\
\hline $\mathrm{Cn} 5$ & 5.00 & 71.38 & 5.64 & 3.67 & 1.67 & 0.03 & 0.90 & 1.28 & 0.30 & 0.03 & 0.16 & 64.65 \\
\hline $\mathrm{Cn} 6$ & 5.54 & 69.87 & 7.44 & 4.09 & 1.80 & 0.03 & 1.31 & 1.69 & 0.40 & 0.03 & 0.50 & 71.30 \\
\hline $\mathrm{Cn} 7$ & 5.40 & 67.60 & 8.93 & 4.35 & 1.08 & 0.03 & 1.68 & 2.01 & 0.48 & 0.03 & 0.18 & 70.73 \\
\hline Cn8 & 5.18 & 57.99 & 8.88 & 4.02 & 1.58 & 0.05 & 1.23 & 1.90 & 0.55 & 0.04 & 0.18 & 73.93 \\
\hline $\mathrm{Cn} 9$ & 4.53 & 68.52 & 9.44 & 3.77 & 0.97 & 0.03 & 1.63 & 2.24 & 0.52 & 0.03 & 0.16 & 70.92 \\
\hline
\end{tabular}




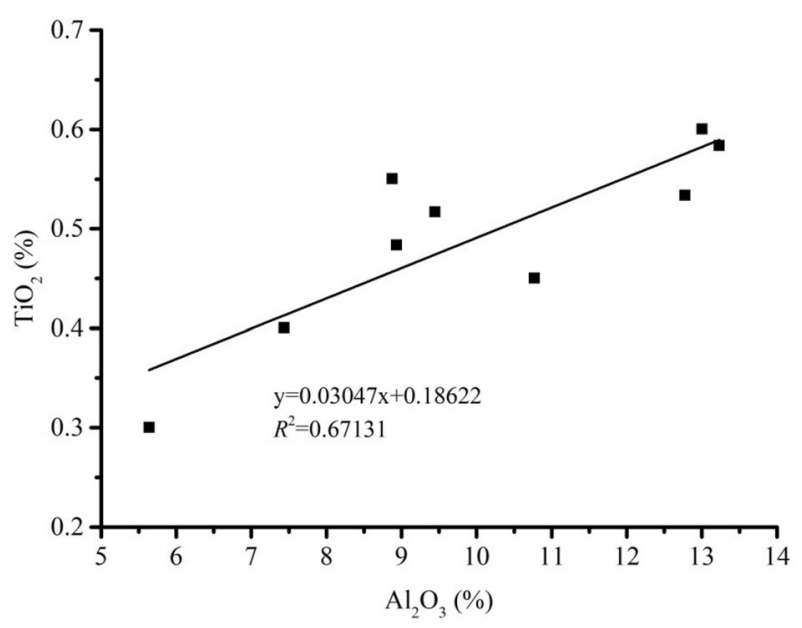

Fig. 5 Relationships between content of $\mathrm{TiO}_{2}$ and $\mathrm{Al}_{2} \mathrm{O}_{3}$ in Niutitang Formation shale samples

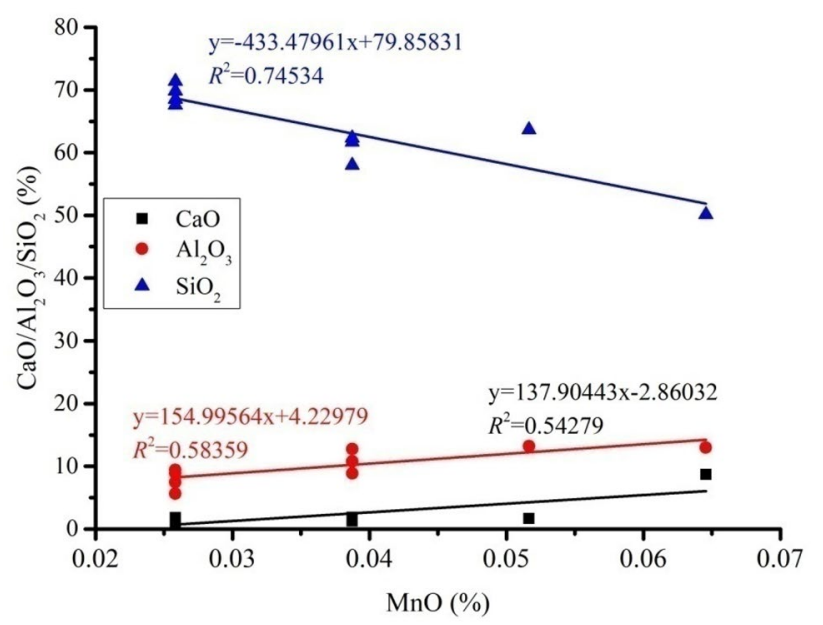

Fig. 6 Relationships between content of $\mathrm{MnO}$ and $\mathrm{CaO}, \mathrm{Al}_{2} \mathrm{O}_{3}, \mathrm{SiO}_{2}$ in Niutitang Formation shale samples

\section{Trace elements geochemistry characteristics}

The trace elements in the Niutitang Formation shale is not enrichment, while that for the vanadium (V), nickel (Ni), cuprum $(\mathrm{Cu})$, zincum $(\mathrm{Zn})$, lead $(\mathrm{Pb})$, strontium $(\mathrm{Sr})$, molybdenum (Mo), barium (Ba), uranium (U) and yttrium (Y) are enrichment (Table 2, Fig. 7).

\section{Lithology characteristics}

The inorganic minerals are quartz, feldspar, carbonate minerals, pyrite and illite in the Niutitang Formation shale. The dominant inorganic mineral is the quartz, the content of the quartz ranges from 31.30 to $63.30 \%$; and the content of illite varies from 13.90 to $26.49 \%$; the content of pyrite ranges from 7.70 to $17.10 \%$; orthoclase and anorthose both exist in the Niutitang Formation shale, and the content of later is higher than that of former; the content of carbonate minerals varies from 5.40 to $22.10 \%$, and the content of calcite and dolomite is almost equal (Table 3 ).

\section{Pores characteristics}

The intergranular pores are dominantly developed in the Niutitang Formation shale, and the intergranular pores distributed with various sizes (Fig. 8); the micro-fractures could be found developed in the mud-particles (Fig. 8b), and the intracrystalline pores are also developed (Fig. 8d). It can be found that the organic matters feature as disseminated for the upper Niutitang Formation shale samples, and the pyrite presents as scattered or framboid, and the content of the pyrite is also less (Fig. 8a-b). With the increase of burial depth, the distribution of the organic matters tends to be larger with disseminated or banded, and the organic matters commonly occur at the edge of the pores or micro-fractures, the content of pyrite also tends to be increased (Fig. 8c-g). When it comes to the bottom of the Niutitang Formation shale, the pyrite features surrounding the organic matters (Fig. 8h-i).

\section{Discussion}

\section{The multi-geochemical indicators for the accumulation of organic matters}

\section{Paleoclimate}

The paleoclimate determines the amounts of organisms, which will finally determine the enrichment of the organic matters. CIA and $\mathrm{EF}_{\mathrm{Sr}}$ are effective indicators that could reflect the paleoclimate. With a range from 50 to 70 for CIA, the paleoclimate is commonly cold and dry, indicating a lower chemical weathering degree; if the CIA varies from 70 to 85 , it indicates a warm and humid paleoclimate, and the chemical weathering is medium; once the CIA exceeds 85 , the paleoclimate is hot and humid, and the chemical weathering is strong (Nesbitt and Young 1982). Sr could enter into the sediments in the warm and humid paleoclimate, which would lead to the enrichment of $\mathrm{Sr}$ in the shale.

The CIA of Niutitang Formation shale ranges from 64.65 to 74.41. The paleoclimate for the lower Niutitang Formation shale is stable, presents as cold and dry, while the paleoclimate for the upper Niutitang Formation shale is fluctuant, the cold and dry paleoclimate alternates with warm and humid paleoclimate. The distribution characteristics of $\mathrm{Sr}$ are similar to CIA, and $\mathrm{Sr}$ tends to be enrichment at the upper Niutitang Formation shale, which indicates the large 
Table 2 Trace elements of Niutitang Formation shales

\begin{tabular}{|c|c|c|c|c|c|c|c|c|c|c|c|c|c|}
\hline \multirow[t]{2}{*}{ Sample } & \multicolumn{13}{|c|}{ Trace elements $/ \mu \mathrm{g} / \mathrm{g}$} \\
\hline & $\mathrm{Li}$ & $\mathrm{Be}$ & Sc & V & $\mathrm{Cr}$ & $\mathrm{Co}$ & $\mathrm{Ni}$ & $\mathrm{Cu}$ & $\mathrm{Zn}$ & $\mathrm{Ga}$ & $\mathrm{Pb}$ & $\mathrm{Rb}$ & $\mathrm{Sr}$ \\
\hline Cn1 & 16.00 & 1.98 & 18.40 & 122.00 & 69.00 & 17.00 & 37.00 & 43.30 & 138.00 & 19.60 & 21.00 & 92.00 & 980.00 \\
\hline $\mathrm{Cn} 2$ & 17.00 & 2.11 & 12.20 & 480.00 & 79.00 & 17.80 & 131.00 & 86.80 & 163.00 & 16.40 & 23.00 & 103.00 & 503.00 \\
\hline $\mathrm{Cn} 3$ & 22.00 & 2.23 & 12.10 & 276.00 & 72.00 & 21.10 & 90.00 & 97.10 & 151.00 & 16.80 & 23.00 & 99.00 & 305.00 \\
\hline $\mathrm{Cn} 4$ & 23.00 & 2.33 & 12.90 & 678.00 & 136.00 & 31.90 & 130.00 & 218.60 & 262.00 & 14.10 & 33.00 & 80.00 & 269.00 \\
\hline Cn5 & 20.00 & 2.01 & 9.90 & 1159.00 & 65.00 & 18.70 & 308.00 & 88.80 & 376.00 & 10.20 & 32.00 & 49.00 & 331.00 \\
\hline Cn6 & 24.00 & 2.10 & 12.20 & 250.00 & 52.00 & 15.20 & 127.00 & 62.80 & 108.00 & 10.40 & 31.00 & 56.00 & 240.00 \\
\hline $\mathrm{Cn} 7$ & 26.00 & 2.42 & 11.30 & 319.00 & 58.00 & 15.60 & 124.00 & 57.20 & 116.00 & 11.20 & 25.00 & 71.00 & 169.00 \\
\hline $\mathrm{Cn} 8$ & 17.00 & 2.05 & 14.70 & 571.00 & 84.00 & 20.30 & 119.00 & 103.30 & 304.00 & 12.20 & 22.00 & 56.00 & 689.00 \\
\hline Cn9 & 26.00 & 2.46 & 11.90 & 2366.00 & 131.00 & 17.80 & 179.00 & 103.10 & 930.00 & 16.10 & 29.00 & 69.00 & 114.00 \\
\hline \multirow[t]{2}{*}{ Sample } & \multicolumn{13}{|c|}{ Trace elements $/ \mu \mathrm{g} / \mathrm{g}$} \\
\hline & $\mathrm{Zr}$ & $\mathrm{Nb}$ & Mo & Cs & $\mathrm{Ba}$ & $\mathrm{Hf}$ & $\mathrm{Ta}$ & Th & $\mathrm{U}$ & $\mathrm{La}$ & $\mathrm{Ce}$ & $\mathrm{Y}$ & Ho \\
\hline $\mathrm{Cn} 1$ & 141.21 & 12.21 & 9.60 & 8.27 & 5378.00 & 3.23 & 1.00 & 8.20 & 5.98 & 28.22 & 52.05 & 32.16 & 0.86 \\
\hline $\mathrm{Cn} 2$ & 145.26 & 10.42 & 58.60 & 7.43 & 5672.00 & 3.37 & 0.80 & 10.60 & 15.95 & 23.48 & 41.69 & 27.20 & 0.82 \\
\hline $\mathrm{Cn} 3$ & 132.03 & 13.63 & 68.80 & 6.75 & $10,604.00$ & 3.04 & 0.70 & 9.90 & 29.52 & 26.37 & 48.18 & 26.72 & 0.81 \\
\hline $\mathrm{Cn} 4$ & 117.72 & 9.07 & 121.30 & 4.99 & $18,010.00$ & 2.64 & 0.60 & 8.80 & 68.58 & 29.15 & 50.82 & 55.04 & 1.06 \\
\hline Cn5 & 73.84 & 5.79 & 268.60 & 2.96 & $23,513.00$ & 1.52 & 0.40 & 5.70 & 122.76 & 21.84 & 33.77 & 50.56 & 0.78 \\
\hline Cn6 & 100.30 & 7.53 & 127.60 & 2.98 & 9576.00 & 2.29 & 0.50 & 6.10 & 100.80 & 28.53 & 45.43 & 57.12 & 0.83 \\
\hline $\mathrm{Cn} 7$ & 131.62 & 8.52 & 116.60 & 3.80 & $14,540.00$ & 2.99 & 0.60 & 7.80 & 86.63 & 29.56 & 48.18 & 40.80 & 0.85 \\
\hline $\mathrm{Cn} 8$ & 145.26 & 9.04 & 75.30 & 2.69 & $84,410.00$ & 3.40 & 0.60 & 6.10 & 56.63 & 26.78 & 43.12 & 55.52 & 0.96 \\
\hline Cn9 & 142.56 & 8.21 & 69.70 & 6.95 & 8461.00 & 3.14 & 0.70 & 6.80 & 42.32 & 28.22 & 40.70 & 60.96 & 1.32 \\
\hline
\end{tabular}

Li-lithium, Be-beryllium, Sc-scandium, V-vanadium, Cr-chromium, Co-cobalt, Ni-nickel, Cu-cuprum, Zn-zincum, Ga-gallium, Pb-lead, Rbrubidium, Sr-strontium, Zr-zirconium, Nb-niobium, Mo-molybdenum, Cs-cesium, Ba-barium, Hf-hafnium, Ta-tantalum, Th-thorium, U-uranium, La-lanthanum, Ce-cerium, Y-yttrium, Ho-holmium

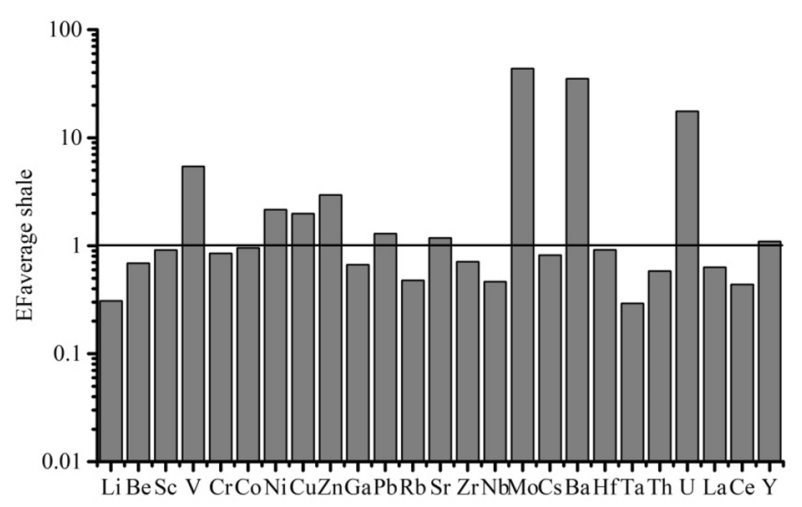

Fig. 7 Enrichment factors of trace elements in Niutitang Formation shale samples

amounts of detrital influx (Fig. 9). The content of TOC just features a faint increase for the lower Niutitang Formation shale under the cold and dry paleoclimate. Although there is a certain amount of terrigenous sediments, the organic matters may dominantly come from marine organisms. For the upper Niutitang Formation shale, the content of TOC tends to be decreased, the massive input of terrigenous sediments dilutes the concentration of organic matters in the shale. The relationships between CIA and content of TOC and $\mathrm{EF}_{\mathrm{Sr}}$ and content of TOC are fluctuant, indicating that the paleoclimate is not the key factor that controls the accumulation of organic matters.

\section{Detrital influx}

The detrital influx presents two sides for the accumulation of the organic matters. For one thing, the detrital influx would dilute the concentration of the existed organic matters; for another thing, the organic matters contained in the detrital influx would increase the content of organic matters in the sediments. $\mathrm{SiO}_{2} / \mathrm{Al}_{2} \mathrm{O}_{3}, \mathrm{MnO} / \mathrm{TiO}_{2}$ and $\mathrm{Y} / \mathrm{Ho}$ are key indicators to distinguish the source of the sediments. For $\mathrm{MnO} / \mathrm{TiO}_{2}$, the value of $\mathrm{MnO} / \mathrm{TiO}_{2}$ below 0.5 means the sediments are mainly from the continental slope and marginal sea (Ryuichi et al. 1982). The value of $\mathrm{SiO}_{2} / \mathrm{Al}_{2} \mathrm{O}_{3}$ for continental crust is approximately 3.6, if $\mathrm{SiO}_{2} / \mathrm{Al}_{2} \mathrm{O}_{3}>3.6$, it indicates that the clastics not only come from the detrital influx, but also from the marine organisms or hydrothermal siliceous. Y/Ho could point out whether the sediments are 
Table 3 The contents of various minerals in Niutitang Formation shales

\begin{tabular}{lllrrrrrrr}
\hline Samples & \multicolumn{1}{l}{ Minerals /\% } \\
\cline { 2 - 10 } & Quartz & Orthoclase & Anorthose & Calcite & Dolomite & Pyrite & Ankerite & I/S & Illite \\
\hline Cn1 & 31.30 & 1.10 & 4.90 & 10.70 & 11.40 & 7.70 & $/$ & 12.50 & 20.40 \\
Cn2 & 40.40 & 1.90 & 10.70 & 1.80 & 5.60 & 8.80 & $/$ & 4.31 & 26.49 \\
Cn3 & 38.40 & 2.90 & 10.10 & 2.50 & 5.30 & 13.20 & $/$ & 9.70 & 18.01 \\
Cn4 & 43.70 & 4.00 & 7.00 & 3.50 & 4.10 & 17.10 & $/$ & $/$ & 20.70 \\
Cn5 & 63.30 & 2.30 & 5.10 & 2.00 & 3.40 & 8.00 & $/$ & $/$ & 15.90 \\
Cn6 & 53.40 & 3.50 & 7.30 & 4.50 & 5.40 & 10.30 & $/$ & $/$ & 15.50 \\
Cn7 & 52.60 & 4.40 & 10.10 & 3.20 & 3.40 & 10.60 & $/$ & $/$ & 15.80 \\
Cn8 & 46.40 & 6.00 & 7.90 & 11.30 & 0.00 & 10.50 & 4.00 & $/$ & 13.90 \\
Cn9 & 49.10 & 4.90 & 11.00 & 4.40 & 3.80 & 9.70 & $/$ & $/$ & 17.20 \\
\hline
\end{tabular}

contaminated by the detrital influx, and it ranges from 44 to 77 for the marine shale (Webb and Kamber 2000).

$\mathrm{SiO}_{2} / \mathrm{Al}_{2} \mathrm{O}_{3}$ exceeds 3.6 for Niutitang Formation shale, and $\mathrm{MnO} / \mathrm{TiO}_{2}$ is significantly less than 0.5 , indicating the multi-sources of siliceous in the Niutitang Formation shale. Y/Ho indicates the lower Niutitang Formation shale is typical marine shale, while that for the upper Niutitang Formation shale is below 44, meaning there is a certain amounts of detrital influx enter into the upper Niutitang Formation shale. The similar distribution characteristics of $\mathrm{SiO}_{2} / \mathrm{Al}_{2} \mathrm{O}_{3}$ and content of TOC and Y/Ho and content of TOC also make clear that the accumulation of organic matters in the Niutitang Formation shale is significantly influenced by the marine organisms and the hydrothermal activity (Fig. 10).

The chemical property of $\mathrm{Al}, \mathrm{Ti}, \mathrm{Zr}$ and $\mathrm{Th}$ is stable, and these elements could also indicate the detrital influx. Al commonly occurs in the clay minerals of shale, $\mathrm{Zr}$ and Th are the composition of the aluminosilicate, Ti could exist in the clay minerals, ilmenite and rutile (Liu et al. 2018). The positive relationship between content of TOC and $\mathrm{SiO}_{2} /$ $\mathrm{Al}_{2} \mathrm{O}_{3}$ indicates the enrichment of organic matter relates to the biogenetic silicon, especially that for the lower Niutitang Formation shale. $\mathrm{EF}_{\mathrm{Th}}$ presents the similar distribution with the content of TOC, while the content of Al features contrary, meaning the detrital influx dilutes the concentration of organic matters in the upper Niutitang Formation shale (Fig. 10).

\section{Redox of the water}

The redox environment of water not only influences the enrichment of organic matters, but also the difference accumulation of the elements. According to the study the enrichment characteristics of various elements, the water environment could be recovered (Meyer et al. 2012; Maslov and Pldkovyrov 2018). V/(V+Ni), V/Cr, Ni/Co, $\mathrm{EF}_{\mathrm{Mo}}, \mathrm{EF}_{\mathrm{U}}$, $\mathrm{EF}_{\mathrm{V}}, \mathrm{EF}_{\mathrm{Ni}}, \mathrm{U} / \mathrm{Th}$ and $\mathrm{Cu} / \mathrm{Zn}$ are commonly used (Algeo and Maynard 2004; Ross and Bustin 2009b; Pi et al. 2014; Zhu et al. 2018). $\mathrm{Ni}$ and $\mathrm{V}$ could enter into the sediments under the reducing environment (Lewan and Maynard 1982; Breit and Wanty 1991), Co and Cr dominantly comes from the detrital influx. With the continuous decrease of oxygen in the water, the content of $\mathrm{Ni}$ and $\mathrm{V}$ would increase, leading to the increase of $\mathrm{Ni} / \mathrm{Co}$ and $\mathrm{V} / \mathrm{Cr}$ in the sediments. $\mathrm{V} / \mathrm{Cr}$ could indicate the oxidation-reduction quality commendably. V/ $\mathrm{Cr}$ exceeds 2 means the oxygen-deficient environment; V/ $\mathrm{Cr}$ ranges from 1 to 2 indicate the weak oxidation environment; and $\mathrm{V} / \mathrm{Cr}<1$ means the oxidation environment (Jones and Manning 1994). Taking the value of 7 as the inflection point, $\mathrm{Ni} / \mathrm{Co}<7$ features an oxidation environment. Th is an inert element under the marine temperature, and it can enrich in the clay minerals. Under the reducing environment, $\mathrm{U} / \mathrm{Th}$ is greater than 1.25; when it is below 0.75, the environment tends to be oxidative (Pattan et al. 2005). For the quiet marine environment, $\mathrm{V} /(\mathrm{V}+\mathrm{Ni})$ ranges from 0.83 to 1 , and $\mathrm{V} /(\mathrm{V}+\mathrm{Ni})<0.57$ indicates the oxidation environment of water (Lewan and Maynard 1982). $\mathrm{Cu} / \mathrm{Zn}<0.2$ commonly means an oxidation environment; conversely, it is a reducing environment.

$\mathrm{Ni}$ /Co ranges from 2.18 to 16.47 for the Niutitang Formation shale, $\mathrm{V} / \mathrm{Cr}$ varies from 1.77 to 18.06 , U/Th changes between 0.73 and $21.54, \mathrm{~V} /(\mathrm{V}+\mathrm{Ni})$ and $\mathrm{Cu} / \mathrm{Zn}$ range from 0.66 to 0.93 and 0.11 to 0.83 , respectively. These indicators suggest that the water environment of the Niutitang Formation shale is dominantly reductive, which favors the preservation of the organic matters. The distribution of $\mathrm{Ni} / \mathrm{Co}, \mathrm{V} /$ $\mathrm{Cr}$, U/Th and $\mathrm{Cu} / \mathrm{Zn}$ is approximately similar, only the $\mathrm{Cn} 5$ sample features as abnormal. Although the water environment presents reductive totally, it increases firstly and then decrease, and this is similar to the distribution of content of TOC, indicating that the redox environment contributes dominantly to the accumulation of the organic matters. For the lower Niutitang Formation shale, $\mathrm{V} /(\mathrm{V}+\mathrm{Ni})$ features continuously decrease, which is contrary to content of TOC, indicating some other accidents that may influence the preservation of the organic matters (Fig. 11).

$\mathrm{U}$ exists as $\mathrm{UO}_{2}\left(\mathrm{CO}_{3}\right)_{3}{ }^{4-}$ in the oxidable marine and features high solubility, and when the marine changes to 


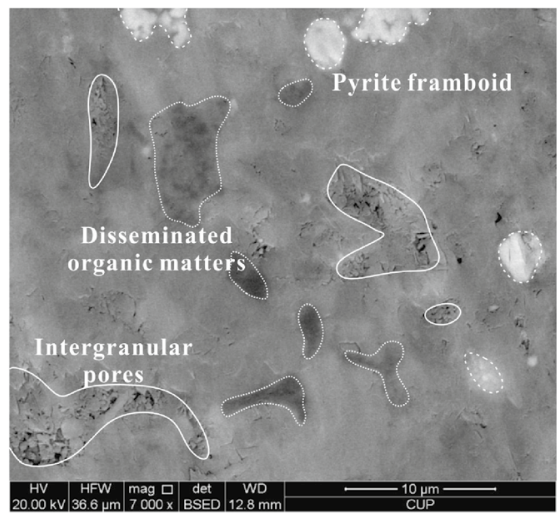

(a) $\mathrm{Cn} 1(\times 7000)$

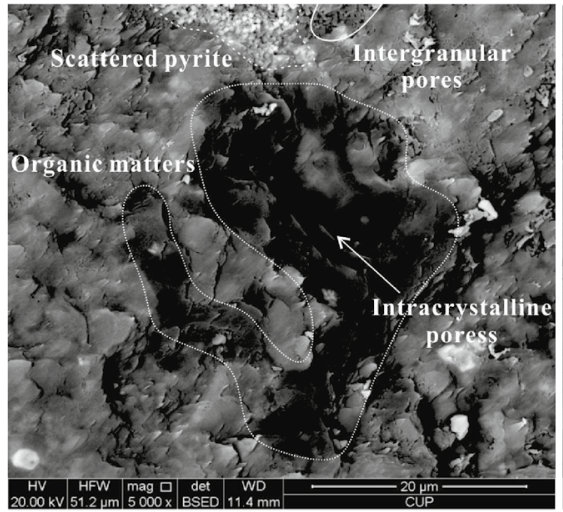

(d) $\mathrm{Cn} 4(\times 5000)$

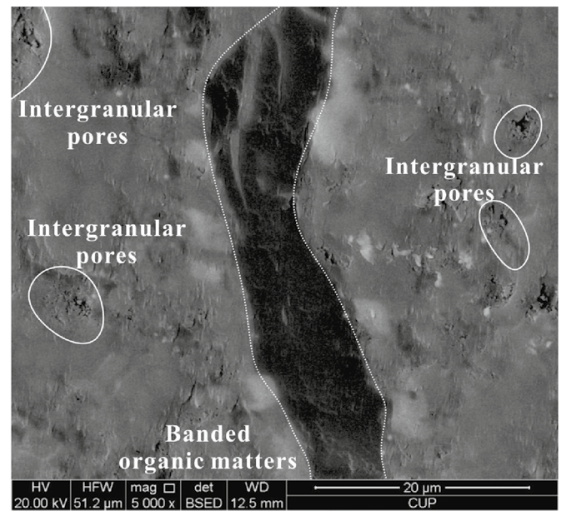

(g) $\mathrm{Cn} 7(\times 5000)$

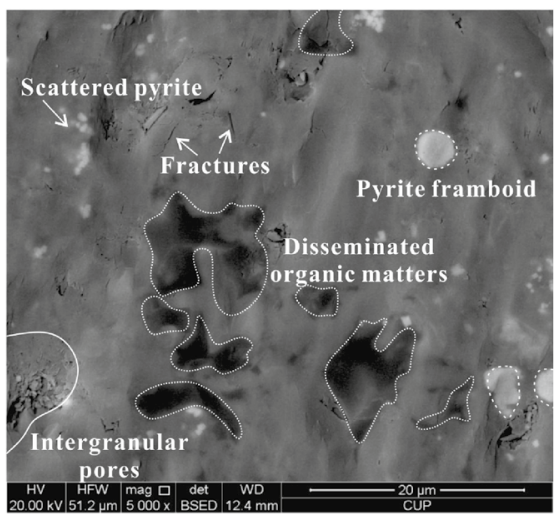

(b) $\mathrm{Cn} 2(\times 5000)$

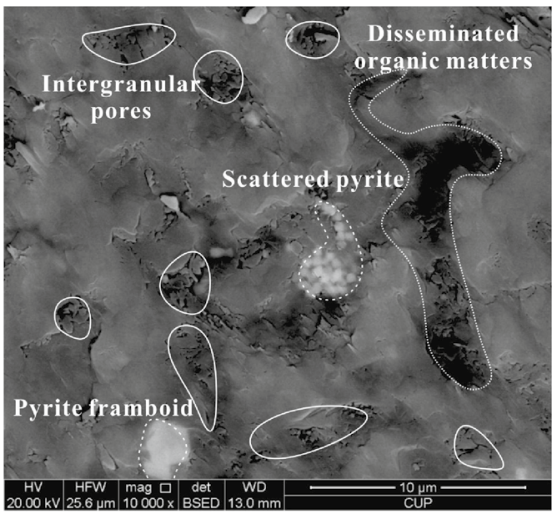

(e) $\operatorname{Cn} 5(\times 10000)$

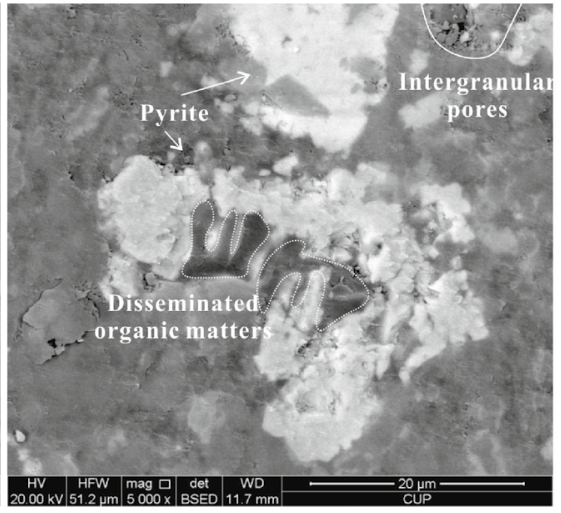

(h) $\mathrm{Cn} 8(\times 5000)$

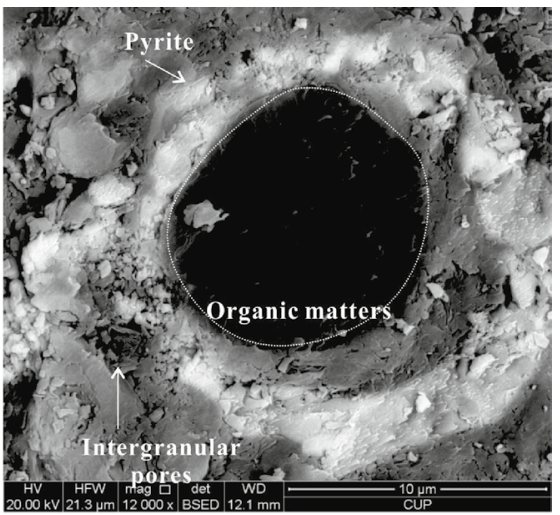

(c) $\mathrm{Cn} 3(\times 12000)$

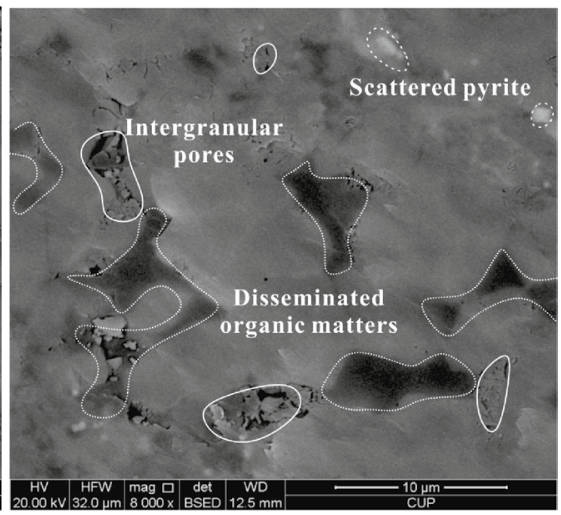

(f) $\mathrm{Cn} 6(\times 8000)$

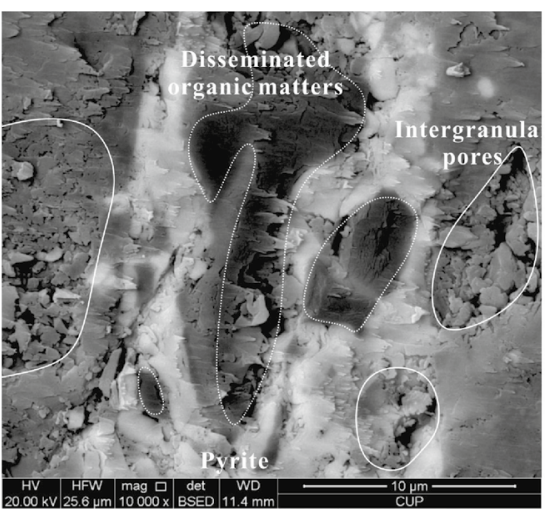

(i) $\mathrm{Cn} 9(\times 10000)$

Fig. 8 The SEM of shale samples in Niutitang Formation

reductive, $\mathrm{UO}_{2}\left(\mathrm{CO}_{3}\right)_{3}{ }^{4-}$ would be reduced to $\mathrm{UO}_{2}, \mathrm{U}_{3} \mathrm{O}_{7}$ and $\mathrm{U}_{3} \mathrm{O}_{8}$ and fixed into the sediments, leading to the enrichment of U (Tribovillard et al. 2006). The phyrin compound separated from chlorophyll contains large amount of $\mathrm{V}$ and $\mathrm{Ni}$. At the acidic reducing environment, $\mathrm{V}^{4+}$ is stable, and $\mathrm{Ni}$ could form sulfide precipitation (Lewan and Maynard 1982). At the non-sulfide reducing environment, the organic matters can adsorb and catch $\mathrm{U}$ and $\mathrm{V}$ in the water, then $\mathrm{U}$ and $\mathrm{V}$ enrich in the organic matters (Algeo and Maynard 2004). When it comes to the sulfide reducing environment, the content of $\mathrm{H}_{2} \mathrm{~S}$ is high in the water, $\mathrm{U}$ and $\mathrm{V}$ enter into the sediments in the form of sulfide or hydroxide, leading to indistinctive relationship between U/Al and content of TOC and V/Al and content of TOC (Ross and Bustin 2009b). The 


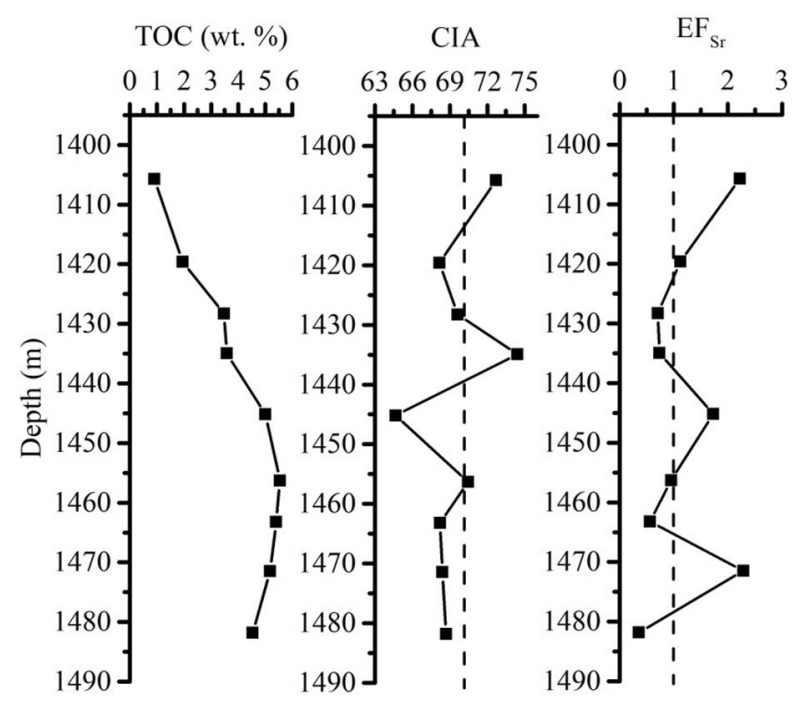

Fig. 9 The vertical distribution characteristics of detrital influx proxies indexes in Niutitang Formation

abnormal characteristics of Ce could also reflect the environment of water (German and Elderfield 1990; Schijf et al. 1991; Wilde et al. 1996). At the oxidative environment, Ce is easily adsorbed by the Fe oxides and Mn oxidex, leading to the positive anomaly or no obvious negative anomaly in the sediments; similarly, in the weak oxidation or reducing environment, Fe oxides would be dissolved, and $\mathrm{Ce}$ would enter into the water, leading to the positive anomaly in the water (Wilde et al. 1996; Yang et al. 2008). The distribution of $\mathrm{U}, \mathrm{V}, \mathrm{Mo}, \mathrm{U} / \mathrm{Th}$ and $\mathrm{Ce}$ is coincident with content of TOC, indicating that the reducibility of the water for Niutitang Formation increases firstly and then decreases (Fig. 11). The relationships between U/Al and content of TOC and V/ $\mathrm{Al}$ and content of TOC are insignificant, especially for the later, indicating that the $\mathrm{U}$ and $\mathrm{V}$ enrich in the shale with two forms, organic matters and sulfide or hydroxide, respectively (Fig. 12), and this is identical with the distribution of V/ (V/Ni).

The enrichment of $\mathrm{V}, \mathrm{Cr}, \mathrm{Ni}, \mathrm{Cu}, \mathrm{Zn}, \mathrm{Mo}, \mathrm{Cd}$ and $\mathrm{Sb}$ and loss of $\mathrm{Sr}, \mathrm{Re}$ and $\mathrm{Zr}$ are commonly related to the hydrothermal activity in the deep water (Steiner et al. 2001). In the marine shale, the ratio of content $\mathrm{Sr}$ and $\mathrm{Ba}(\mathrm{Sr} / \mathrm{Ba})$ is greater than 1 , while in the sediments of modern seafloor, it is below 1, the smaller $\mathrm{Sr} / \mathrm{Ba}$ indicates strong hydrothermal activity (Guo et al. 2007). The ratio of content Co and $\mathrm{Zn}$ $(\mathrm{Co} / \mathrm{Zn})$ is an impressible parameter to indicate the hydrothermal activity (Toth 1980). Influenced by the hydrothermal activity, $\mathrm{Co} / \mathrm{Zn}$ is less than 0.15 in average (Toth 1980). Sr/ Ba ranges from 0.01 to 0.18 , and $\mathrm{Co} / \mathrm{Zn}$ is below 0.15 , indicating that the Niutitang Formation shale is influenced by the hydrothermal activity, especially that for the lower shale (Table 2). Due to the hydrothermal activity, the content of flint in the Niutitang Formation shale is high, and the rapidly sedimentary hydrothermal silica fluid provides a good preservation environment for the organic matters (Xie et al. 2021).

The locally closed sea basin leads to the difference accumulation of trace elements due to the obtained cycle of circulation of the bottom water. Algeo and Lyons (2006)
Fig. 10 The vertical distribution characteristics of TOC, $\mathrm{SiO}_{2} /$ $\mathrm{Al}_{2} \mathrm{O}_{3}, \mathrm{MnO} / \mathrm{TiO}_{2}, \mathrm{Y} / \mathrm{Ho}, \mathrm{Al}$, $\mathrm{EF}_{\mathrm{Ti}}, \mathrm{EF}_{\mathrm{Zr}}$ and $\mathrm{EF}_{\mathrm{Th}}$ in Niutitang Formation

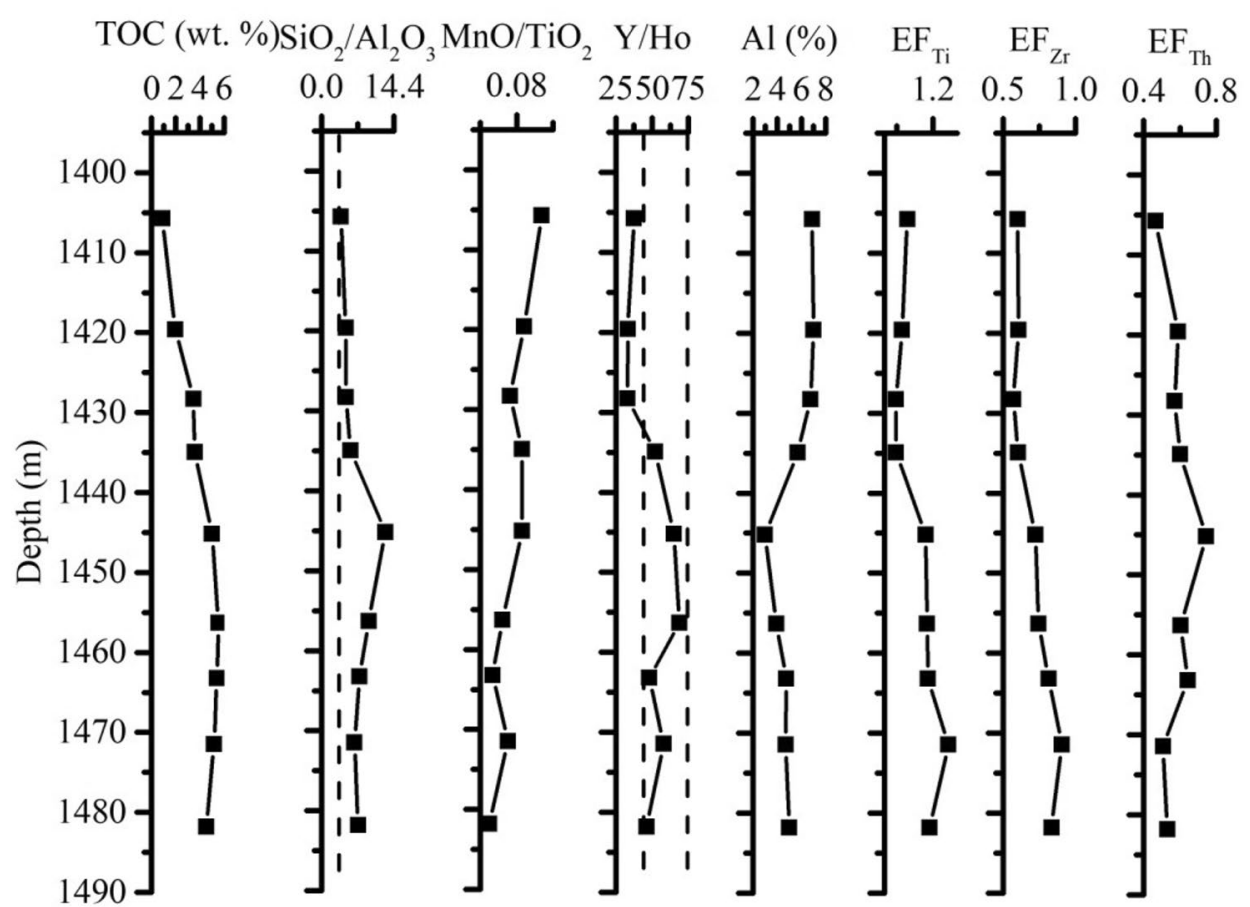


Fig. 11 The vertical distribution characteristics of various redox proxies indexes in Niutitang Formation

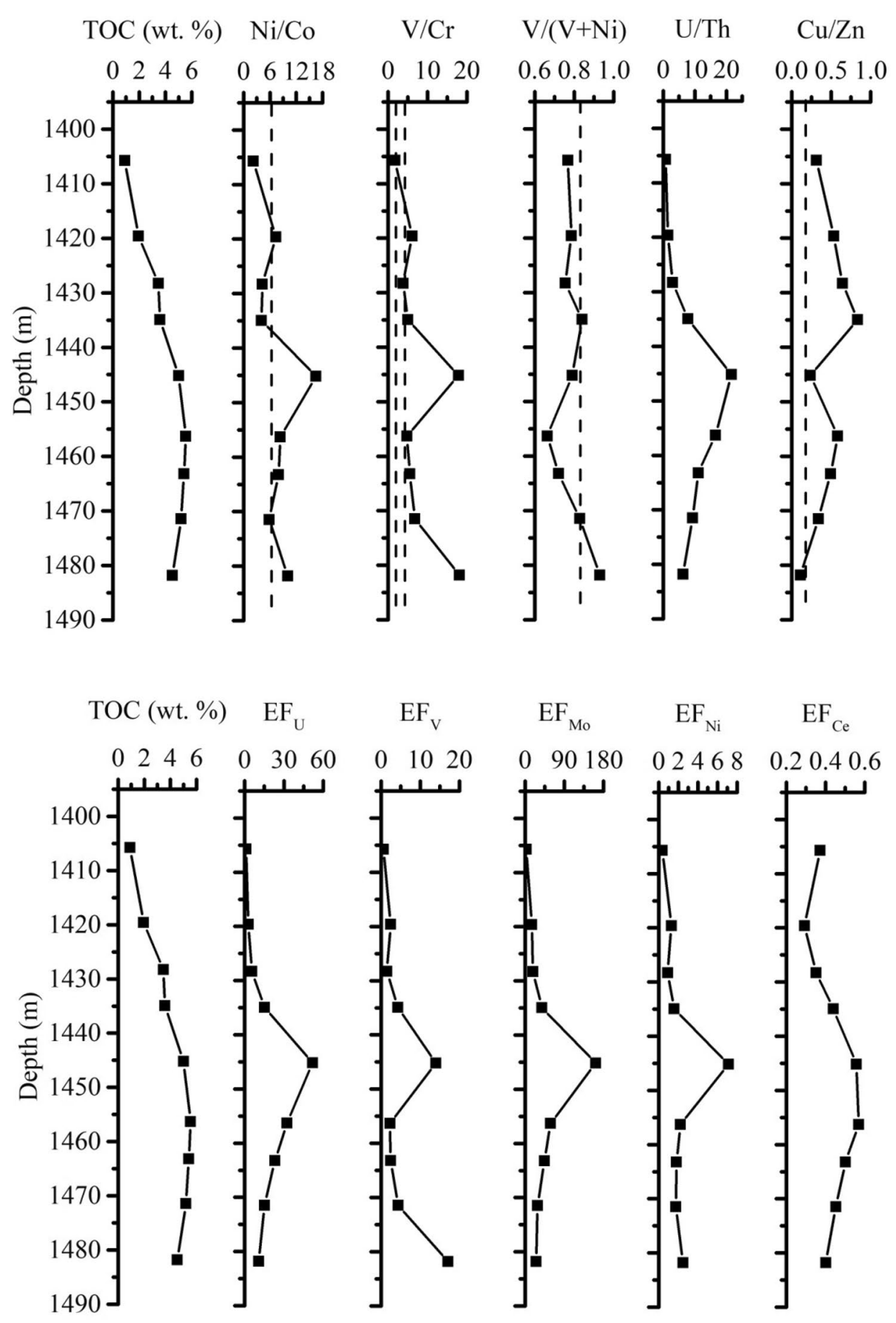

reported the Mo-TOC model to define the retention degree of basin water. Mo is a sensitive element in reflecting the redox environment. It can be enriched at the reducing environment, while it is easily influenced by the organic matters in the sediments, and there is a coupling relationship between the ratio of content Mo and TOC (Mo/TOC) and Mo concentration in the sea water. In the open sea, Mo in the sea water is enough, it can enter into the sediments largely, leading to a high Mo/TOC; in the locally closed water, the supplement of Mo is slow or inactive, leading to a low Mo concentration in the bottom water, especially the reducing water environment, Mo/TOC is comparatively low (Tribovillard et al. 2012). For the Niutitang Formation shale, the water environment features as moderate retention, and it reaches to maximum in the medium term (Fig. 13). 


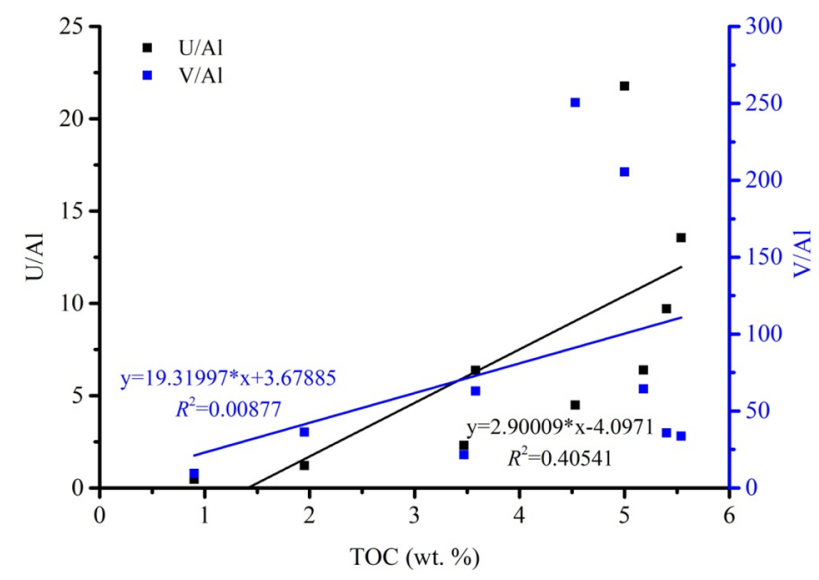

Fig. 12 The relationship between TOC and U/Al and V/Al in Niutitang Formation

\section{Paleoproductivity}

$\mathrm{P}$ and $\mathrm{Ba}$ are indicators to evaluate the paleoproductivity of the marine, while these elements could be diluted by the clastics, and $\mathrm{P} / \mathrm{Ti}$ and $\mathrm{Ba} / \mathrm{Al}$ are replaced (Dean et al. 1997; Algeo et al. 2011; Liu et al. 2018).

$\mathrm{P} / \mathrm{Ti}$ ranges from 0.17 to 0.96 for the Niutitang Formation shale, and it is higher than that of the marine shale, indicating relative high productivity (Murray et al. 1993). $\mathrm{P} / \mathrm{Ti}$ features as increase firstly and then decrease from the bottom to the top, and the lower Niutitang Formation shale presents higher P/Ti than that of the upper Niutitang Formation shale, which is similar to the distribution of content of TOC (Fig. 14). However, it should notice that the $\mathrm{Cn} 6$ and
Cn4 shale samples present high $\mathrm{P} / \mathrm{Ti}$, while the content of TOC has not reached to the maximum, and this may relate to the redox environment of water. The reducibility of water for $\mathrm{Cn} 4$ sample is still strong, the high content of $\mathrm{Fe}$ in the water may adsorb $\mathrm{P}$, leading to greater $\mathrm{P} / \mathrm{Ti}$ and lower content of TOC (Algeo and Ingall 2007; Westermann et al. 2013).

$\mathrm{Ba} / \mathrm{Al}$ varies from $782.82 \times 10^{-4}$ to $17,997.87 \times 10^{-4}$ for Niutitang Formation shale, this is higher than the paleoproductivity of the layer sediments at continental margin of central California (Dean et al. 1997), indicating high paleoproductivity of Niutitang Formation shale. The distribution of $\mathrm{Ba} / \mathrm{Al}$ and content of TOC presents high uniformity (Fig. 14). However, $\mathrm{Ba} / \mathrm{Al}$ of $\mathrm{Cn} 8$ sample is maximum, while the water is reducibility (Chen et al. 2016), this may be related to the hydrothermal activity, which leads to the positive anomaly of Ba concentration.

\section{The accumulation model of organic matters}

The accumulation of organic matters for the Niutitang Formation shale is dominantly influenced by the redox environment. The paleoclimate is dominantly dry and cold during the sedimentary of Niutitang Formation shale, which does not favor the preservation of the organic matter. With the paleoclimate changes to warm and humid, the content of organic matters even decreases (Fig. 15). The relationships between $\mathrm{Si}$ and content of TOC, $\mathrm{U}$ and content of TOC, P/ $\mathrm{Ti}$ and content of TOC and $\mathrm{Ba}$ and content of TOC present positive correlation, especially that for the $\mathrm{Si}$ and $\mathrm{U}$, indicating that the deep water reducing environment favors the preservation of the organic matters and biogenic siliceous (Fig. 15). However, due to the hydrothermal activity and
Fig. 13 The relationship between TOC and Mo in Niutitang Formation

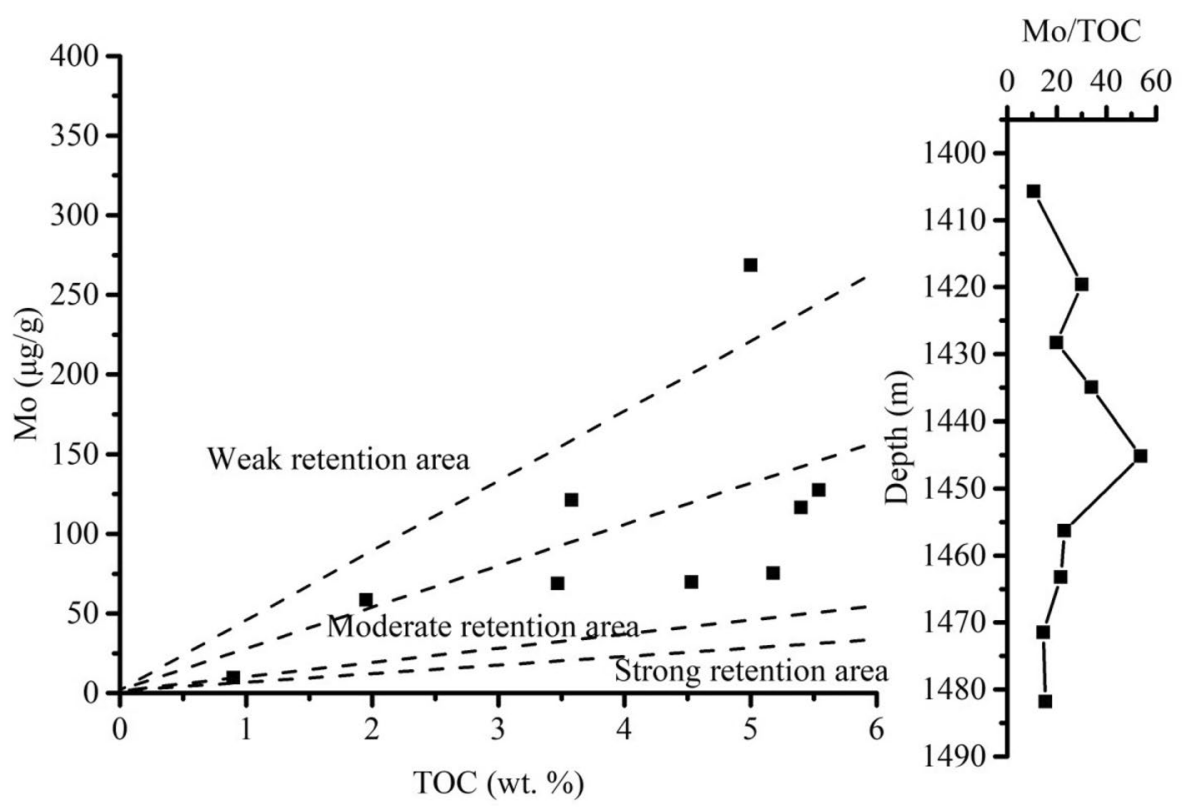

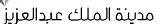
KACST 
Fig. 14 The vertical distribution characteristics of various paleoproductivity proxies indexes in Niutitang Formation

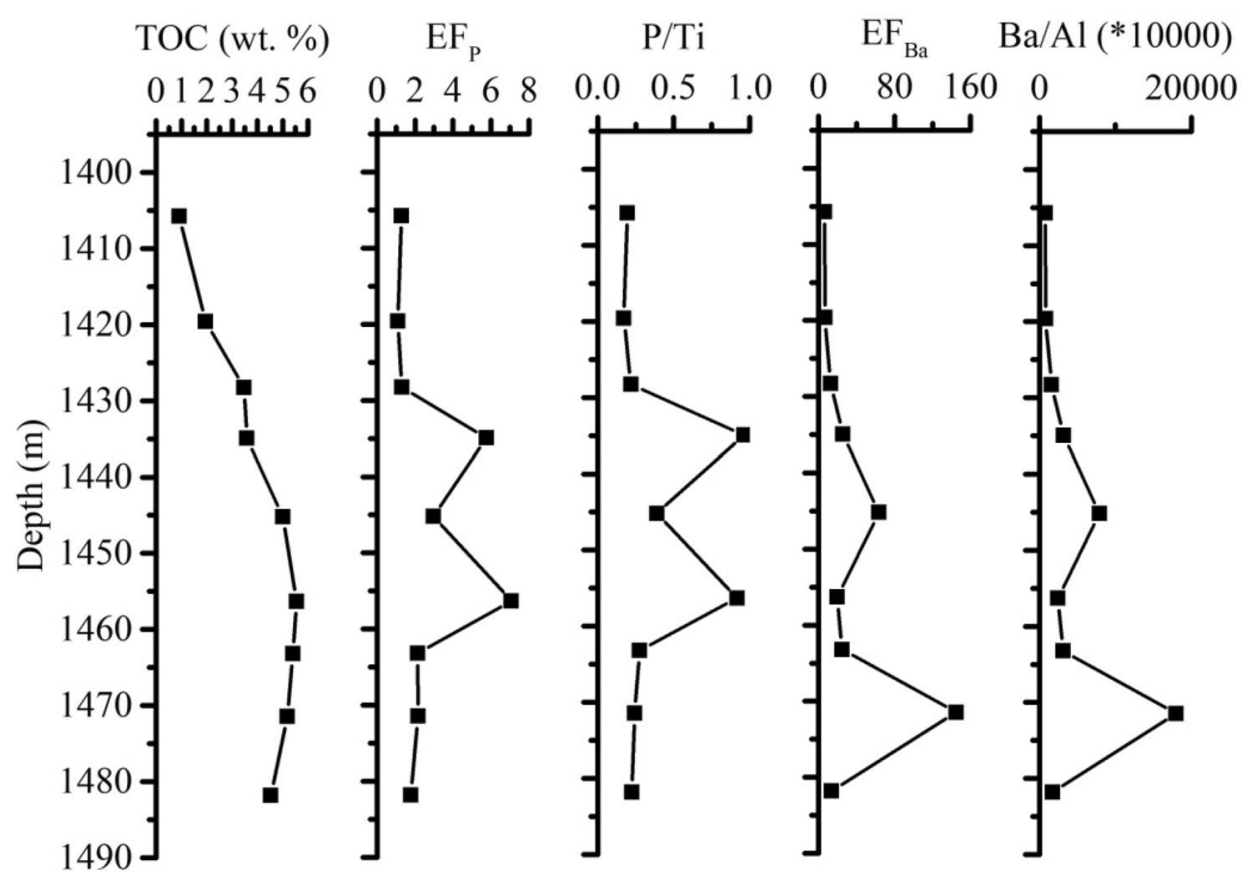

the paleoclimate, the contribution of paleoproductivity to the accumulation of organic matters is not significant when it compares with the redox environment of water. Besides, the detrital influx from the continental slope or marginal sea has diluted the concentration of organic matters in the upper Niutitang Formation shale (Fig. 15).

\section{The control of accumulation of organic matters on pore structure}

\section{The relationship between accumulation of organic matters and lithology characteristics}

The quartz, pyrite, feldspar, clay minerals and carbonate minerals are dominant inorganic minerals in the Niutitang Formation shale. The distribution of the content of quartz and pyrite is approximately coincident with that of the TOC, while it is contrary with the content of clay minerals, and the distribution of the content of feldspar and carbonate minerals is mussy (Fig. 16). Due to the reducing water environment, both the organic matters and the biogenic siliceous are preserved; combined with the hydrothermal activity, massive hydrothermal silica fluid and sulfide enter into the Niutitang Formation shale, which finally promotes the content of quartz and pyrite. The clay minerals mainly come from the detrital influx, which dilutes the concentration of the organic matters, leading to a negative relationship between the content of TOC and clay minerals. The contents of feldspar and carbonate minerals show faint influence on the content of organic matters due to the limited amounts.

\section{Characteristics of pore structure}

The low-pressure nitrogen adsorption $\left(\mathrm{LP}-\mathrm{N}_{2} \mathrm{~A}\right)$ curves of the Niutitang Formation shale samples show as IV type, and these curves could be divided into two different types according to the shape of the hysteresis loop. The hysteresis loops of $\mathrm{Cn} 4$ and $\mathrm{Cn} 5$ samples feature as $\mathrm{H}_{3}$ type, while that for the other shale samples present as $\mathrm{H}_{4}$ type, these mean the different shapes of pores in the Niutitang Formation shale (Fig. 17). The $\mathrm{H}_{3}$ type hysteresis loop indicates the pores in the shale are dominant slit and wedge shape lamellar pores, while the $\mathrm{H}_{4}$ type hysteresis loop means the parallel plate-shaped pores are dominant.

The distribution of pore aperture could also be distinguished into two types. The $\mathrm{Cn} 4$ and $\mathrm{Cn} 5$ samples feature two peaks for the distribution of the pore apertures, the left peak of the pore aperture ranges from 3 to $4 \mathrm{~nm}$, and the right peak of the pore aperture varies from 5 to $30 \mathrm{~nm}$. As for the other shale samples, the pore aperture only features one peak, ranging from 3 to $4 \mathrm{~nm}$ (Fig. 18). The location of the $\mathrm{Cn} 4$ and $\mathrm{Cn} 5$ samples is the deep water reducing environment, which favors the preservation of the organic matters and biogenic siliceous. Corresponding to the lithology characteristics, the content of quartz and pyrite is high, while that for the clay minerals are low. As the rigid minerals, the quartz and pyrite could preserve the shape and space of the pores, which contributes to the greater pore aperture in the Niutitang Formation shale. Besides, the minor amount of the plastic minerals would also not fill into the pores. The relationships between the pore specific surface area and content of TOC and the

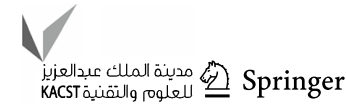



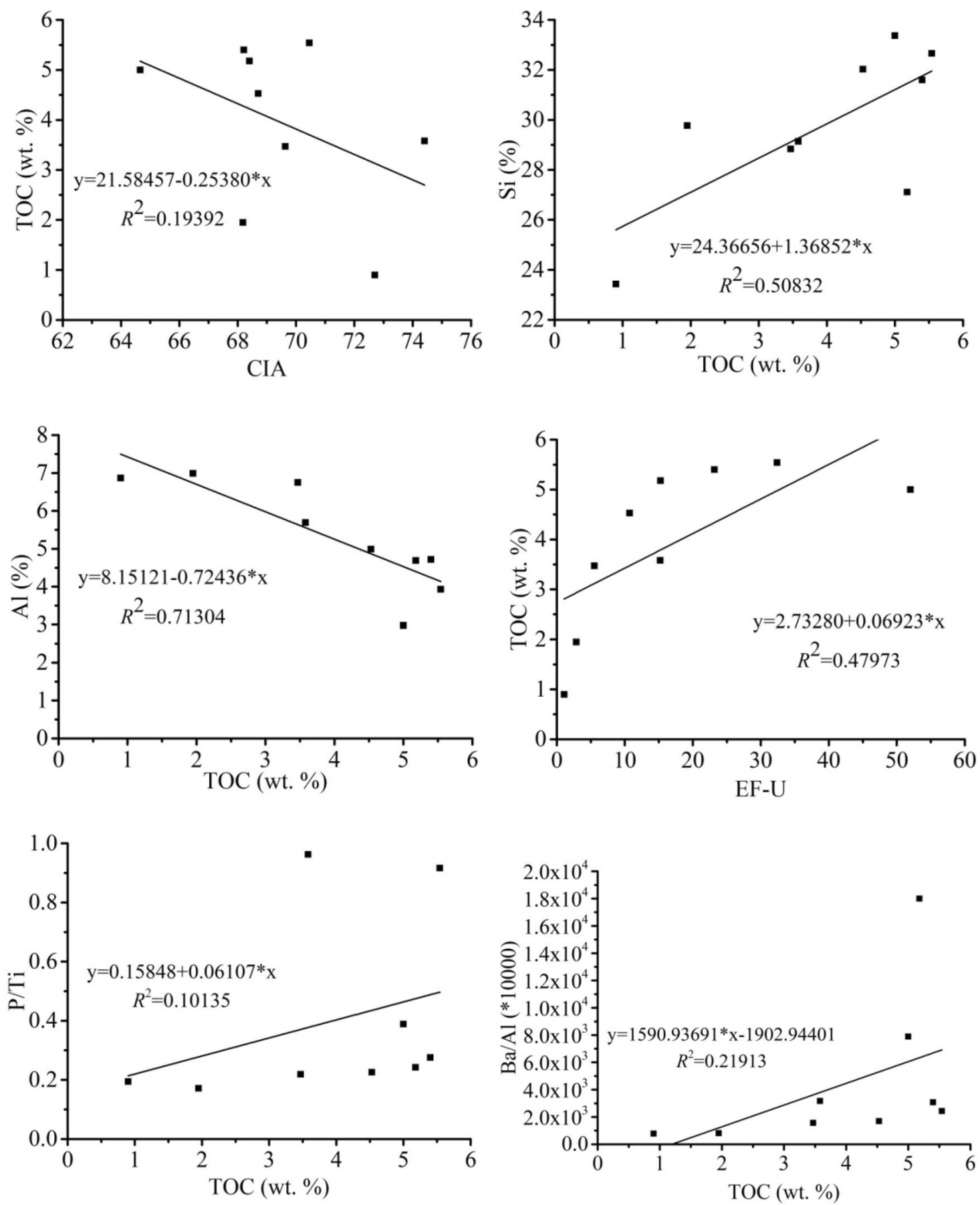

Fig. 15 The relationship between TOC and CIA, $\mathrm{Si}, \mathrm{Al}, \mathrm{EF}_{\mathrm{U}}, \mathrm{P} / \mathrm{Ti}$ and $\mathrm{Ba} / \mathrm{Al}$ in Niutitang Formation

pore specific surface area and the quartz also indicate that the new-born nanoscale pores also contribute to development of pores during the thermal evolution procedures. The cleats and intracrystalline pores developed in the clay minerals are compacted, and the dissolved pores are not developed in the feldspar and carbonate minerals, which do not favor the development of the pores (Fig. 19).

\section{Conclusions}

1) The content of organic matters in the Niutitang Formation shale is high, especially that for the lower Niutitang Formation shale. As the major elements, $\mathrm{Mg}$ and $\mathrm{Mn}$ show a certain deficit, while the other features as enrichment. The trace elements in the Niutitang Formation 
Fig. 16 The relationship between TOC and content of minerals in Niutitang Formation
TOC (wt. \%) Quartz (\%) Pyrite (\%) Clay minerals (\%) Feldspar (\%) Carbonate minerals (\%)

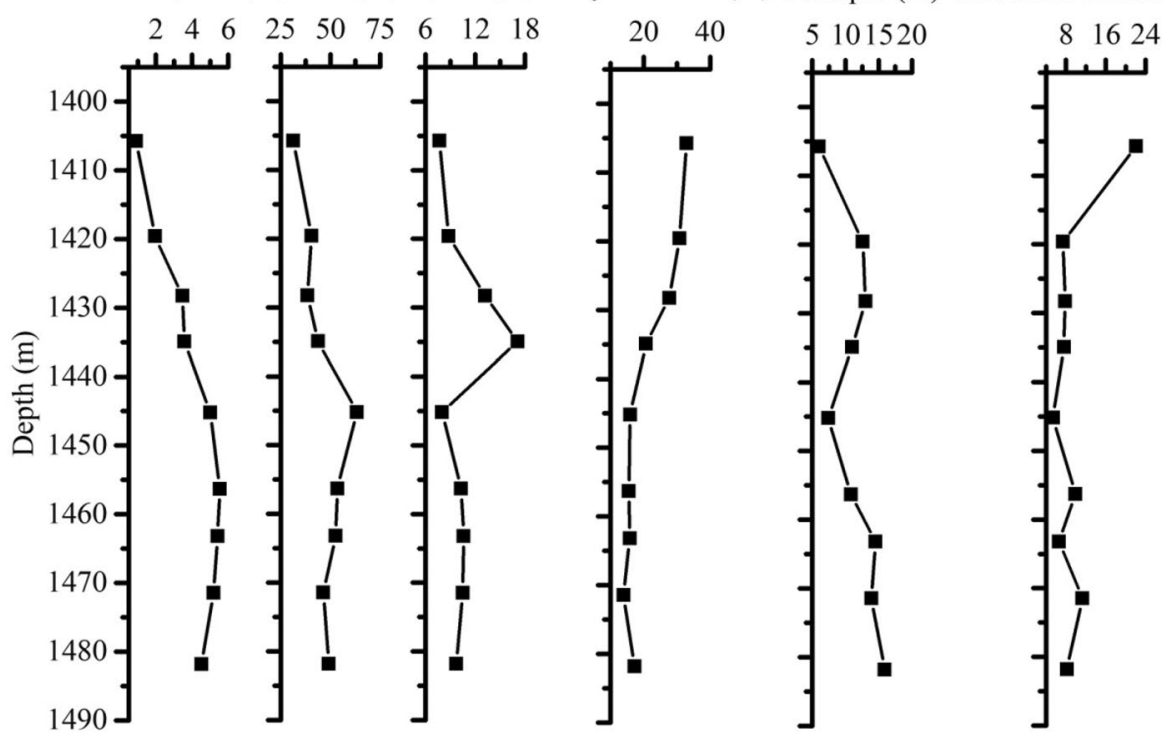

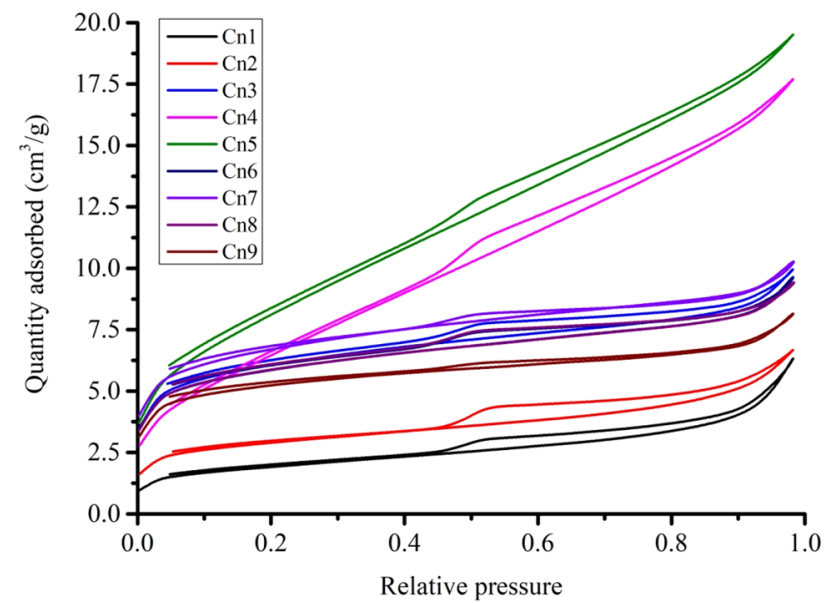

Fig. 17 The LP- ${ }_{2} \mathrm{~A}$ curves of shales in Niutitang Formation shale presents dominantly deficit. The minerals in the Niutitang Formation shale are dominantly quartz, clay minerals, pyrite, feldspar and carbonate minerals, and the Niutitang Formation shale features as enrichment of siliceous.

2) The paleoclimate of Niutitang period features cold and dry, it tends to be warm and humid at the later Niutitang period, while there is no obvious relationship between the content of organic matters and paleoclimate. The siliceous in the Niutitang Formation shale presents as multi-sources, it is biogenetic siliceous in the lower Niutitang Formation shale, and it is dominantly detrital siliceous for the upper Niutitang Formation shale, and this leads to the decrease of the content of organic matters. The water environment is reductive, which dominantly controls the accumulation of organic matters, the paleo-
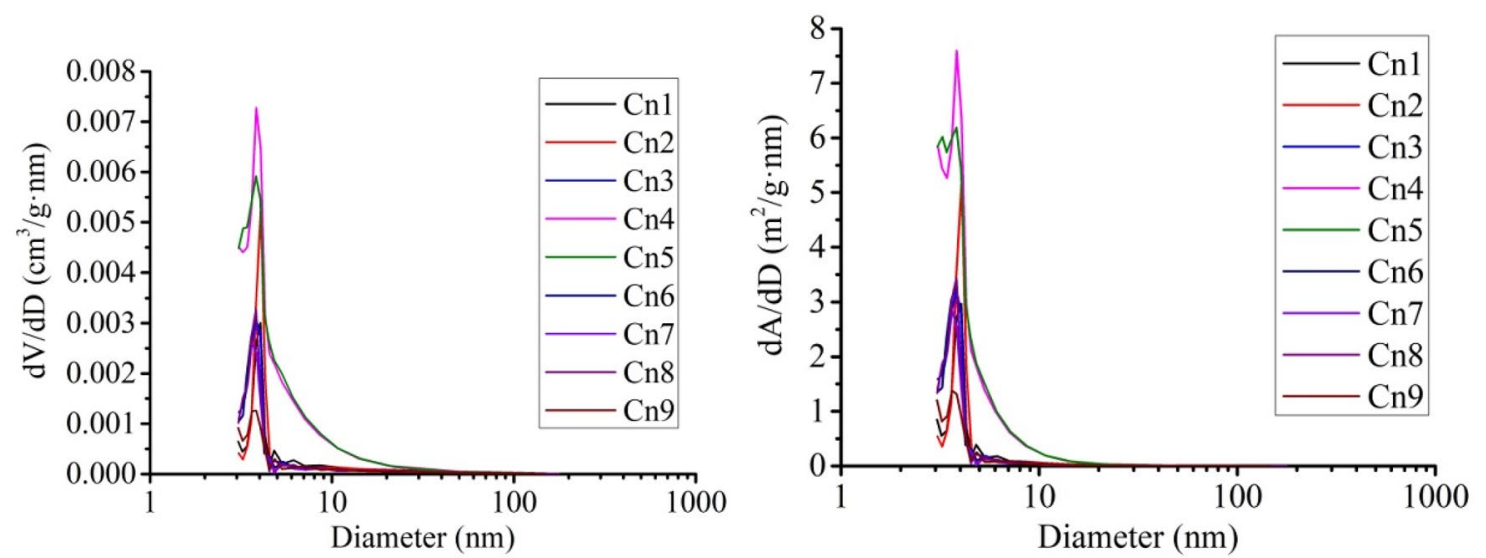

Fig. 18 The incremental pore volume and pore specific surface area curves of shales in Niutitang Formation 

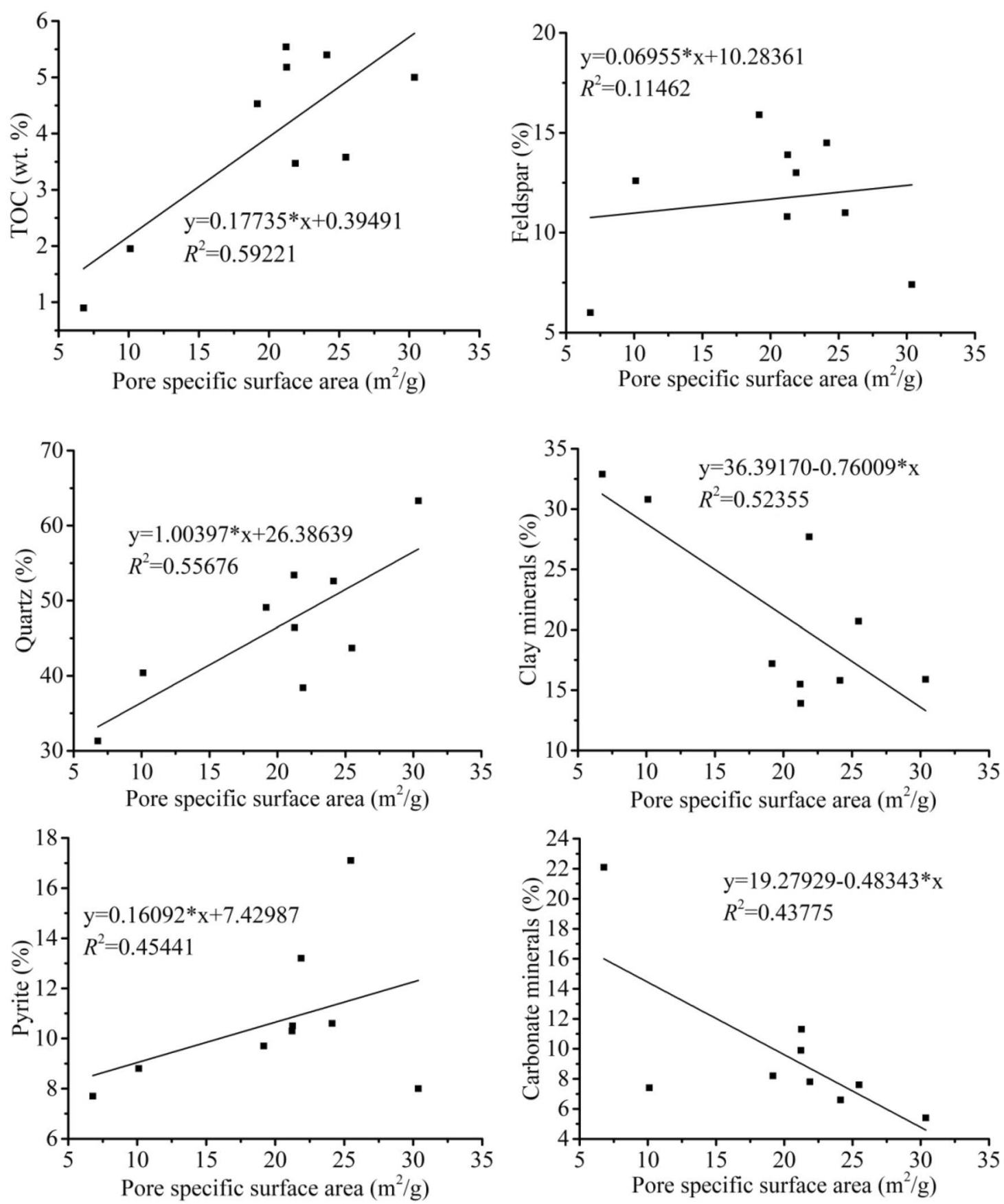

Fig. 19 The relationships of pores and minerals for shales in Niutitang Formation

productivity and hydrothermal activity contribute to the difference enrichment of organic matters.

3) Influenced by the accumulation of the organic matters, the pore structure in the Niutitang Formation shale could be divided into two different types. In the middle of the Niutitang Formation shale, the pores distribute into two sections, $3 \mathrm{~nm}$ to $4 \mathrm{~nm}$ and $5 \mathrm{~nm}$ to $30 \mathrm{~nm}$, respectively, and this is mainly due to the strong reducing environment, hydrothermal activity and the productivity. The pore structure parameters show highly consistence with the content of TOC, quartz and pyrite, it indicates the sedimentary environment not only influences the accumulation of the organic matters, but also the lithology characteristics, and this finally controls the development of the pores in the shale.

4) The characteristics of enrichment of organic matters and pore structure indicate the Niutitang Formation shale is favorable for the development of shale gas, and the 
lower Niutitang Formation shale would be the sweet spot stratum.

Funding This work was supported by the National Natural Science Foundation of China (Program No. 52174030 and Program No. 52004219), Scientific Research Program Funded by Shaanxi Provincial Education Department (Program No.21JP095 and Program No. 20JS116), The Youth Innovation Team of Shaanxi Universities, Natural Science Basic Research Program of Shaanxi (Program No. 2020JQ-781), and Open Fund of State Key Laboratory of Shale Oil and Gas Enrichment Mechanisms and Effective Development (Grant No. G5800-20-ZS-KFGY018).

\section{Declarations}

Conflict of interest The authors declare that they have no known competing financial interests or personal relationships that could have appeared to influence the work reported in this paper.

Open Access This article is licensed under a Creative Commons Attribution 4.0 International License, which permits use, sharing, adaptation, distribution and reproduction in any medium or format, as long as you give appropriate credit to the original author(s) and the source, provide a link to the Creative Commons licence, and indicate if changes were made. The images or other third party material in this article are included in the article's Creative Commons licence, unless indicated otherwise in a credit line to the material. If material is not included in the article's Creative Commons licence and your intended use is not permitted by statutory regulation or exceeds the permitted use, you will need to obtain permission directly from the copyright holder. To view a copy of this licence, visit http://creativecommons.org/licenses/by/4.0/.

\section{References}

Algeo TJ, Ingall E (2007) Sedimentary $\mathrm{C}_{\text {org }}$ : P ratios, paleocean ventilation, and Phanerozoic atmospheric $\mathrm{pO}_{2}$. Palaeogeogr Palaeoclimatol Palaeoecol 256(3-4):130-155. https://doi.org/10.1016/j. palaeo.2007.02.029

Algeo TJ, Lyons TW (2006) Mo-total organic carbon covariation in modern anoxic marine environments: Implicatons for analysis of paleoredox and paleohydrographic condition. Paleoceanography Paleoclimatology 21(1):1016-1038. https://doi.org/10.1029/ 2004PA001112

Algeo TJ, Maynard JB (2004) Trace-element behavior and redox facies in core shales of Upper Pennsylvanian Kansas-type cyclothems. Chem Geol 206(3-4):289-318. https://doi.org/10.1016/j.chemg eo.2003.12.009

Algeo TJ, Kuwahara K, Sano H, Bates S, Lyons T, Elswick E, Hinnov L, Ellwood B, Moser J, Maynard JB (2011) Spatial variation in sediment fluxes, redox conditions, and productivity in the Permian-Triassic Panthalassic Ocean. Palaeogeogr Palaeoclimatol Palaeoecol 308(1-2):65-83. https://doi.org/10.1016/j.palaeo. 2010.07.007

Arthur MA, Sageman BB (1994) Marine black shales: depositional mechanisms and environments of ancient deposition. Annual Rev Earth Planet Sci 22:499-551. https://doi.org/10.1146/annurev.ea. 22.050194.002435
Arthur MA, Dean WE, Laarkamp K (1998) Organic carbon accumulation and preservation in surface sediments on the Peru margin. Chem Geol 152(3-4):273-286. https://doi.org/10.1016/S00092541(98)00120-X

Awan RS, Liu C, Gong H, Dun C, Tong C, Chamssidini LG (2020) Paleo-sedimentary environment in relation to enrichment of organic matter of Early Cambrian black rocks of Niutitang Formation from Xiangxi area China. Mar Pet Geol 112:104057. https:// doi.org/10.1016/j.marpetgeo.2019.104057

Breit GN, Wanty RB (1991) Vanadium accumulation in carbonaceous rocks: a review of geochemical controls during deposition and diagenesis. Chem Geol 91(2):83-97. https://doi.org/10.1016/ 0009-2541(91)90083-4

Carroll AR, Bohacs KM (1999) Stratigraphic classification of ancient lakes: balancing tectonic and climatic controls. Geology 27(2):99-102. https://doi.org/10.1130/0091-7613(1999)027\% 3C0099:SCOALB\%3E2.3.CO;2

Chen C, Mu CL, Zhou KK, Liang W, Ge XY, Wang XP, Wang QY, Zheng BS (2016) The geochemical characteristics and factors controlling the organic matter accumulation of the Late Ordovician-Early Silurian black shale in the Upper Yangtze Basin, South China. Mar Pet Geol 76:159-175. https://doi.org/10. 1016/j.marpetgeo.2016.04.022

Dean WE, Gardner JV, Piper DZ (1997) Inorganic geochemical indicators of glacial-interglacial changes in productivity and anoxia on the California continental margin. Geochemica Et Cosmochimica Acta 61(21):4507-4518. https://doi.org/10.1016/ S0016-7037(97)00237-8

Demaison GJ, Moore GT (1980) Anoxic environments and oil source bed genesis. Org Geochem 2:9-31. https://doi.org/10.1016/ 0146-6380(80)90017-0

Dong T, He Q, He S, Zhai G, Zhang Y, Wei S, Wei C, Hou Y, Guo X (2021) Quartz types, origins and organic matter-hosted pore systems in the lower cambrian Niutitang Formation, middle yangtze platform. China Marine Petroleum Geology 123:104739. https://doi.org/10.1016/j.marpetgeo.2020.104739

German CR, Elderfield H (1990) Rare earth elements in the NW Indian Ocean. Geochim Cosmochim Acta 54:1929-1940. https://doi.org/10.1016/0016-7037(90)90262-J

Gu Y, Wan Q, Yu W, Li X, Yu Z (2018) The effects of clay minerals and organic matter on nanoscale pores in Lower Paleozoic shale gas reservoirs, Guizhou. China Acta Geochimica 37(6):791804. https://doi.org/10.1007/s11631-018-0295-2

Guo Q, Shields GA, Liu C, Strauss H, Zhu M, Pi D, Goldberg T, Yang X (2007) Trace element chemostratigraphy of two Ediacaran-Cambrian successions in South China: implications for organosedimentary metal enrichment and silicification in the early Cambrian. Palaeogeogr Palaeoclimatol Palaeoecol 254(12):194-216. https://doi.org/10.1016/j.palaeo.2007.03.016

Guo S, Zhu YM, Liu Y, Tang X (2021) Characteristics and controlling factors of nanopores of the Niutitang Formation shale from Jiumen Outcrop, Guizhou Province. J Nanosci Nanotechnol 21(1):284-295. https://doi.org/10.1166/jnn.2021.18455

Jones B, Manning DAC (1994) Comparison of geochemical indices used for the interpretation of palaeoredox conditions in ancient mudstones. Chem Geol 111(1-4):111-129. https://doi.org/10. 1016/0009-2541(94)90085-X

Lewan MD, Maynard JB (1982) Factors controlling enrichment of vanadium and nickel in the bitumen of organic sedimentary rocks. Geochim Cosmochim Acta 46(12):2547-2560. https:// doi.org/10.1016/0016-7037(82)90377-5

Li J, Tang S, Zhang S, Xi Z, Yang N, Yang G, Li L, Li Y (2018) Paleo-environmental conditions of the Early Cambrian Niutitang Formation in the Fenggang area, the southwestern margin of the Yangtze Platform, southern China: Evidence from major

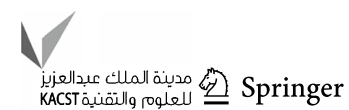


elements, trace elements and other proxies. J Asian Earth Sci 159:81-97. https://doi.org/10.1016/j.jseaes.2018.03.013

Li D, Li R, Tan C, Zhao D, Xue T, Zhao B, Khaled A, Liu F, Xu F (2019) Origin of silica, paleoenvironment, and organic matter enrichment in the Lower Paleozoic Niutitang and Longmaxi formations of the northwestern Upper Yangtze Plate: significance for hydrocarbon exploration. Mar Pet Geol 103:404-421. https://doi.org/10.1016/j.marpetgeo.2019.02.025

Liu ZH, Zhuang XG, Teng GE, Xie XM, Yin LM, Bian LZ, Feng QL, Algeo TJ (2015) The Lower Cambrian Niutitang Formation at Yangtiao (Guizhou, sw China): organic matter enrichment, source rock potential, and hydrothermal influences. J Pet Geol 38(4):411-432. https://doi.org/10.1111/.jpg.12619

Liu J, Yao Y, Elsworth D, Pan Z, Sun X, Ao W (2016) Sedimentary characteristics of the Lower Cambrian Niutitang shale in the southeast margin of Sichuan Basin, China. J Nat Gas Sci Eng 36:1140-1150. https://doi.org/10.1016/j.jngse.2016.03.085

Liu S, Wu C, Li T, Wang H (2018) Multiple geochemical proxies controlling the organic matter accumulation of the marine-continental transitional shale: a case study of the Upper Permian Longtan Formaiton, western Guizhou, China. J Nat Gas Sci Eng 56:152-165. https://doi.org/10.1016/j.jngse.2018.06.007

Ma Y, Lu Y, Liu X, Zhai G, Wang Y, Zhang C (2019) Depositional environment and organic matter enrichment of the lower Cambrian Niutitang shale in western Hubei Province, South China. Mar Pet Geol 109:381-393. https://doi.org/10.1016/j.marpetgeo. 2019.06.039

Maslov AV, Podkovyrov VN (2018) Ocean redox state at 2500-500 Ma: modern concepts. Lithol Min Resour 53:190-211. https:// doi.org/10.1134/S0024490218030057

McLennan SM (1993) Weathering and global denudation. J Geol 101(2):295-303. https://doi.org/10.1086/648222

Meyer EE, Quicksall AN, Landis JD, Link PK, Bostick BC (2012) Trace and rare earth elemental investigation of a Sturtian cap carbonate, Pocatello, Idaho: evidence for ocean redox conditions before and during carbonate deposition. Precambr Res 192 195:89-106. https://doi.org/10.1016/j.precamres.2011.09.015

Murray RW, Leinen M, Isern AR (1993) Biogenic flux of Al to sediment in the central equatorial Pacific Ocean: evidence for increased productivity during glacial periods. Paleoceanography Paleoclimatology 8(5):651-670. https://doi.org/10.1029/93PA0 2195

Nesbitt HW, Young G (1982) Early Proterozoic climates and plate motions inferred from major element chemistry of lutites. Nature 299:715-717. https://doi.org/10.1038/299715a0

Niu X, Yan D, Hu M, Liu Z, Wei X, Zuo M (2021) Controls of distinct mineral compositions on pore structure in over-mature shales: a case study of Lower Cambrian Niutitang shales in South China. Minerals 11(1):51. https://doi.org/10.3390/min11010051

Pattan JN, Pearce NJG, Mislankar PG (2005) Constraints in using Cerium-anomaly of bulk sediments as an indicator of paleo bottom water redox environment: a case study from the central Indian Ocean basin. Chem Geol 221(3-4):260-278. https://doi.org/10. 1016/j.chemgeo.2005.06.009

Pi DH, Jiang SY, Luo L, Yang JH, Ling HF (2014) Depositional environments for stratiform witherite deposits in the Lower Cambrian black shale sequence of the Yangtze Platform, southern Qinling region, SW China: evidence from redox-sensitive trace element geochemistry. Palaeogeography Palacoclimatology Palaeoecology 398:125-131. https://doi.org/10.1016/j.palaeo.2013.09.029

Qin M, Cao Z, Guo J, Huang Y, Sun L, Dong L (2019) Characteristics of shale reservoir and sweet spot identification of the Lower Cambrian Niutitang Formation in Northwestern Hunan Province. China Acta Geologica Sinica (English Edition) 93(3):573-587. https://doi.org/10.1111/1755-6724.13861
Ross DJK, Bustin RM (2008) Characterizing the shale gas resource potential of Devonian-Mississippian strata in the Western Canadian sedimentary basin: application of an integrated formation evaluation. AAPG Bull 92:87-125. https://doi.org/10.1306/09040 707048

Ross DJK, Bustin RM (2009a) Investigating the use of sedimentary geochemical proxies for paleoenvironment interpretation of thermally matrure organic-rich strata: examples from the DevonianMississippian shales. West Canadian Sediment Basin Chem Geology 260(1-2):1-19. https://doi.org/10.1016/j.chemgeo.2008.10. 027

Ross DJK, Bustin RM (2009b) The importance of shale composition and pore structure upon gas storage potential of shale gas reservoirs. Mar Pet Geol 26:916-927. https://doi.org/10.1016/j.marpe tgeo.2008.06.004

Ryuichi S, Koshi Y, Mamoru A (1982) Triassic bedded cherts in central Japan are not pelagic. Nature 298:644-647. https://doi.org/ $10.1038 / 298644 \mathrm{a} 0$

Schijf J, de Bear HJW, Wijbrans JR, Landing WM (1991) Dissolved rare earth elements in the black sea. Deep sea research part A. Oceanographic Res Papers 38:S805-S823. https://doi.org/10. 1016/S0198-0149(10)80010-X

Shang FH, Zhu YM, Gao HT, Wang Y, Liu RY, Meng XW (2021) Analysis of developmental characteristics and dominant factors of pore-fracture systems in Lower Cambrian Marine shale reservoirs: a sase study of the Niutitang Formation, Fenggang Block, Southern China. J Nanosci Nanotechnol 21(1):57-71. https://doi. org/10.1166/jnn.2021.18461

Steiner M, Wallis E, Erdtmann BD, Zhao Y, Yang R (2001) Submarinehydrothermal exhalative ore layers in black shales from South China and associated fossils-insights into a Lower Cambrian facies and bio-evolution. Palaeogeography Palaeoclimatology Palaeoeclogy 169:165-191. https://doi.org/10.1016/S0031-0182(01) 00208-5

Sun M, Yu B, Hu Q, Chen S, Xia W, Ye R (2016) Nanoscale pore characteristics of the Lower Cambrian Niutitang Formation Shale: a case study from Well Yuke \#1 in the Southeast of Chongqing, China. Int J Coal Geol 154-155:16-29. https://doi.org/10.1016/j. coal.2015.11.015

Sun M, Yu B, Hu Q, Yang R, Zhang Y, Li B, Melnichenko YB, Cheng G (2018) Pore structure characterization of organic-rich Niutitang shale from China: small angle neutron scattering (SANS) study. Int J Coal Geol 186:115-125. https://doi.org/10.1016/j.coal.2017. 12.006

Sun W, Zuo Y, Wu Z, Liu H, Zheng L, Wang H, Shui Y, Lou Y, Xi S, Li T, Luo X (2020) Pore characteristics and evolution mechanism of shale in a complex tectonic area: case study of the Lower Cambrian Niutitang Formation in Northern Guizhou, Southwest China. J Petrol Sci Eng 193:107373. https://doi.org/10.1016/j. petrol.2020.107373

Sun W, Zuo Y, Wu Z, Liu H, Zheng L, Shui Y, Xi S, Lou Y, Luo $X$ (2021) The distribution characteristics of brittle minerals in the Lower Cambrian Niutitang Formation in northern Guizhou. J Nat Gas Sci Eng 86:103752. https://doi.org/10.1016/j.jngse.2020. 103752

Talbot MR (1988) The origins of lacustrine oil source rocks: evidence from the lakes of tropical Africa. Geological Soc Lond Spec Publ 40:29-43. https://doi.org/10.1144/GSL.SP.1988.040.01.04

Toth JR (1980) Deposition of submarine crusts rich in manganese and iron. GSA Bull 91(1):44-54. https://doi.org/10.1130/00167606(1980)91\%3C44:DOSCRI\%3E2.0.CO;2

Tribovillard N, Algeo TJ, Lyons T, Riboullean A (2006) Trace metals as paleoredox and paleoproductivity proxies-An update. Chem Geol 232(1-2):12-32. https://doi.org/10.1016/j.chemgeo.2006. 02.012 
Tribovillard N, Algeo TJ, Baudin F, Riboulleau A (2012) Analysis of marine environmental conditions based on molybdenum-uranium covariation-applications to Mesozoic paleoceanography. Chem Geol 324-325:46-58. https://doi.org/10.1016/j.chemgeo.2011. 09.009

Wang P, Jiang Z, Chen L, Yin L, Li Z, Zhang C, Tang X, Wang G (2016a) Pore structure characterization for the Longmaxi and Niutitang shales in the Upper Yangtze Platform, South China: Evidence from focused ion beam-He ion microscopy, nano-computerized tomography and gas adsorption analysis. Mar Pet Geol 77:1323-1337. https://doi.org/10.1016/j.marpetgeo.2016.09.001

Wang R, Ding W, Zhang Y, Wang Z, Wang X, He J, Zeng W, Dai P (2016b) Analysis of developmental characteristics and dominant factors of fractures in Lower Cambrian marine shale reservoirs: a case study of Niutitang formation in Cen'gong block, southern China. J Petrol Sci Eng 138:31-49. https://doi.org/10.1016/j.petrol.2015.12.004

Wang R, Gu Y, Ding W, Gong G, Yin S, Wang X, Zhou X, Li A, Xiao Z, Cui Z (2016c) Characteristics and dominant controlling factors of organic-rich marine shales with high thermal maturity: A case study of the Lower Cambrian Niutitang Formation in the Cen'gong block, southern China. J Nat Gas Sci Eng 33:81-96. https://doi.org/10.1016/j.jngse.2016.05.009

Wang P, Yao S, Jin C, Li X, Zhang K, Liu G, Zang X, Liu S, Jiang $Z$ (2020a) Key reservoir parameter for effective exploration and development of high-over matured marine shales: a case study from the cambrian Niutitang formation and the silurian Longmaxi formation, south China. Mar Pet Geol 121:104619. https://doi.org/ 10.1016/j.marpetgeo.2020.104619

Wang P, Zhang C, Li X, Zhang K, Yuan Y, Zang X, Cui W, Liu S, Jiang Z (2020b) Organic matter pores structure and evolution in shales based on the he ion microscopy (HIM): a case study from the Triassic Yanchang, Lower Silurian Longmaxi and Lower Cambrian Niutitang shales in China. J Nat Gas Sci Eng 84:103682. https:// doi.org/10.1016/j.jngse.2020.103682

Wang Y, Wu C, Qin Y, Liu S, Zhang R (2021) Multi-angle investigation of the fractal characteristics of nanoscale pores in the lower cambrian Niutitang Shale and their implications for $\mathrm{CH}_{4}$ adsorption. J Nanosci Nanotechnol 21(1):156-167. https://doi.org/10. 1166/jnn.2021.18463

Webb GE, Kamber BS (2000) Rare earth elements in Holocene reefal microbialites: a new shallow seawater proxy. Geochim Cosmochim Acta 64(5):1557-1565. https://doi.org/10.1016/S00167037(99)00400-7

Wedepohl KH (1971) Environmental influences on the chemical composition of shales and clays. Phys Chem Earth 8:307-333. https:// doi.org/10.1016/0079-1946(71)90020-6

Westermann S, Stein M, Matera V, Fiet N, Fleitmann D, Adatte T, Föllmi KB (2013) Rapid changes in the redox conditions of the western Tethys Ocean during the early Aptian oceanic anoxic event. Geochemica Et Cosmochimica Acta 121:467-486. https:// doi.org/10.1016/j.gca.2013.07.023

Wignall PB, Newton R (2001) Black shales on the basin margin: a model based on examples from the Upper Jurassic of the Boulonnais, northern France. Sed Geol 144(3-4):335-356. https://doi. org/10.1016/S0037-0738(01)00125-7

Wilde P, Quinby-Hunt MS, Erdtmann BD (1996) The whole-rock cerium anomaly: a potential indicator of eustatic sea-level changes in shales of the anoxic facies. Sed Geol 101(1-2):43-53. https:// doi.org/10.1016/0037-0738(95)00020-8

Wu Y, Fan T, Jiang S, Yang X (2017) Lithofacies and sedimentary sequence of the lower Cambrian Niutitang shale in the upper
Yangtze platform, South China. J Nat Gas Sci Eng 43:124-136. https://doi.org/10.1016/j.jngse.2017.04.002

Xi Z, Tang S, Li J, Zhang Z, Xiao H (2019) Pore characterization and the controls of organic matter and quartz on pore structure: case study of the Niutitang Formation of northern Guizhou Province, South China. J Nat Gas Sci Eng 61:18-31. https://doi.org/10. 1016/j.jngse.2018.11.001

Xia W, Yu B, Sun M (2015) Depositional settings and enrichment mechanism of organic matter of the black shales at the bottom of Niutitang Formation, Lower Cambrian in Southeast Chongqing: a case study from Well Yuke 1. Acta Geologica Sinica (English Edition) 89:287. https://doi.org/10.1111/1755-6724.12304_30

Xie X, Zhu G, Wang Y (2021) The influence of syngenetic hydrothermal silica fluid on organic matter preservation in lower Cambrian Niutitang Formation. South China Marine Petroleum Geology 129:105098. https://doi.org/10.1016/j.marpetgeo.2021.105098

Yang R, Wei H, Bao M, Wang W, Wang Q, Zhang X, Liu L (2008) Discovery of hydrothermal venting community at the base of Cambrian barite in Guizhou Province, Western China: Implicaiton for the Cambrian biological explosion. Prog Nat Sci 18:65-70. https://doi.org/10.1016/j.pnsc.2007.07.006

Yang X, Fan T, Wu Y (2016) Lithofacies and cyclicity of the Lower Cambrian Niutitang shale in the Mayang Basin of western Hunan, South China. J Nat Gas Sci Eng 28:74-86. https://doi.org/10. 1016/j.jngse.2015.11.007

Yarincik KM, Murray RW, Peterson L (2000) Climatically sensitive eolian and hemipelagic deposition in the Cariaco Basin, Venezuela, over the past 578,000 years: results from $\mathrm{Al} / \mathrm{Ti}$ and K/Al. Paleoceanography Paleoclimatology 15(2):210-228. https://doi. org/10.1029/1999PA900048

Zeng SQ, Wang J, Fu XG, Chen WB, Feng XL, Wang D, Song CY, Wang ZW (2015) Geochemical characteristics, redox conditions, and organic matter accumulation of marine oil shale from the Changliang Mountain area, northern Tibet, China. Mar Pet Geol 64:203-221. https://doi.org/10.1016/j.marpetgeo.2015.02.031

Zhang YY, He LZ, Jiang S, Lu SF, Xiao DS, Chen GH, Zhao JH (2018) Controls on the organic carbon content of the lower Cambrian black shale in the southeastern margin of Upper Yangtze. Pet Sci 15:709-721. https://doi.org/10.1007/s12182-018-0262-X

Zhou L, Kang Z, Wang Z, Peng Y, Xiao H (2017) Sedimentary geochemical investigation for paleoenvironment of the Lower Cambrian Niutitang Formation shales in the Yangtze Platform. J Petrol Sci Eng 159:376-386. https://doi.org/10.1016/j.petrol.2017.09. 047

Zhou L, Wang Z, Gao W, Zhang K, Li H, Zhang L (2019) Provenance and tectonic setting of the lower Cambrian Niutitang formation shales in the Yangtze platform, South China: implications for depositional setting of shales. Geochemistry 79(2):384-398. https:// doi.org/10.1016/j.chemer.2019.05.001

Zhu B, Jiang S, Pi D, Ge L, Yang J (2018) Trace elements characteristics of black shales from the Ediacaran Doushantuo formation, Hubei province, South China: implicaitons for redox and open vs restricted basin conditions. J Earth Sci 29(2):342-352. https://doi. org/10.1007/s12583-017-0907-5

Publisher's Note Springer Nature remains neutral with regard to jurisdictional claims in published maps and institutional affiliations. 